\title{
Psikolojide Yöntem Sorunlarına Eleștirel Yaklaşım ve Öneriler
}

\section{A Critical Approach to Methodological Problems in Psychology and Suggestions}

\author{
Meral Gezici Yalçın¹ ${ }^{1}$, Canan Coşkan² (1)
}

Yazar notu: Bu yazıya iki yazar da eşit katkıda bulunmuştur.

'Doç. Dr., Bolu Abant İzzet Baysal Üniversitesi, Fen Edebiyat Fakültesi, Psikoloji Bölümü, Bolu, Türkiye

${ }^{2}$ Dr., Bağımsız araştırmacı; Bielefeld University, Institute for Interdisciplinary Research on Conflict and Violence ile bilimsel ilişkili

ORCID: M.G.Y. 0000-0002-8751-3428; C.C. $0000-0003-0963-8951$

\section{Sorumlu yazar/Corresponding author: \\ Meral Gezici Yalçın \\ Bolu Abant İzzet Baysal Üniversitesi, Fen Edebiyat Fakültesi, Psikoloji Bölümü, Gölköy, \\ Bolu, Türkiye \\ E-posta/E-mail: \\ meralgeziciyalcin@ibu.edu.tr}

Başvuru/Submitted: 21.12.2020 Revizyon Talebi/Revision Requested: 23.02.2021

Son Revizyon/Last Revision Received: 07.06.2021

Kabul/Accepted: 09.06.2021

Online Yayın/Published Online: 20.12.2021

Citation/Atıf: Gezici Yalcin, M. ve Coskan, C. (2021). Psikolojide yöntem sorunlarına eleştirel yaklaşım ve öneriler. Psikoloji Çalışmaları - Studies in Psychology, 41(3), 759-787.

https://doi.org/10.26650/SP2020-844357
ÖZ

Bağımsız bir alan olarak ortaya çıktığı günden bu yana doğa bilimlerinin tümdengelimci araştırma yöntemine yönelen, bu yöntemi tek taraflı, Batı merkezci ve sadece yanlışlama ilkesi temelinde kullanan psikoloji bilimi, günümüzde devasa sorunlarla karşı karşıya. Bu sorunlar karşısında açık bilim ve ön-kayıtlanma uygulaması gibi bazı çözüm önerileri geliştirilse de bir bütün olarak psikoloji disiplininin tarihsel eleştirisinin yapıldığı az sayıda eser göze çarpıyor. Bu nedenle bu yazıda amacımız öncelikle paradigmalar açısından psikoloji tarihine kısa bir göz atarak her şeyin nasıl başladığını hatırlamak. Bunun ardından, ontolojik ve epistemolojk pozisyonumuzu ortaya koymak için psikolojiye eleştirel yaklaşım ve güncel kuir feminist bilim çalışmaları temelinde epistemolojik çeşitlilik, düşünümsellik, öznelerarasılık, konumlandırılmış ve bağlamlandırılmış bilgi üretme ilkelerini ayrıntılandırıyor ve bu ilkeleri psikoloji çalışmalarının merkezinde tutmanın önemine değiniyoruz. Takiben, çoklu paradigmaların ve karma yaklaşımların diyalektik bir şekilde ve önerdiğimiz ilkeler çerçevesinde eleştirel bir yaklaşımla kullanılmasının psikolojinin farklı alanlarındaki genel yöntem sorunlarına çözüm olabileceği savını tartışıyoruz. Yöntem konusuna eleştirel bir pencereden bakmanın, içinde farklı yöntemlerin ve tekniklerin bulunduğu bir 'alet çantası' metaforuyla yaklaşmanın, psikolojinin yöntembilimsel sorunlarını aşmaya yönelik katkılarının neler olabileceğini irdeliyoruz. Bu esnada, çoklu ve karma yöntemleri kısaca tanıtıyor ve psikolojideki kullanımlarına yönelik güncel tartışmaları özetliyoruz. Kısaca bu yazıda, psikolojinin toplumsal sorunların çözümüne katkısının, çoklu ve karma yöntemlerin eleştirel bakış açısıyla alan yazını da dönüştürecek bir amaçla kullanılmasıyla artabileceği savını ortaya atıyoruz. Bu çerçevede, eleştirel bakış açısı için gerekli temel ilkelerle (düşünümsellik, öznelerarasılık, konumlandırılmış bilgi) yola çıkıldığında, bilginin (ve dolayısıyla verinin) türünden (nitel veya nicel) ziyade, bilginin hangi amaçla ve kim için üretildiği sorusunun daha önemli bir tartışma zemini yaratabileceğini ileri sürüyoruz.

Anahtar Kelimeler: Psikolojide yöntem sorunları, bilimsel paradigmalar, nitel ve nicel yöntemler, eleştirel yaklaşım, düşünümsellik, konumlandırılmış bilgi 


\section{ABSTRACT}

Psychological science faces paramount problems for its inclination toward using deductive methods through a singlesided and western-centrist perspective, which is solely based on the principle of falsifiability since its declaration of disciplinary independence. Although several solutions, such as open science and pre-registration practices, have been developed to counteract these problems, paucity exists in research that presents a historical critique of the discipline of psychology. For this reason, we firstly aim to remember the foundation of this discipline in terms of the paradigms of the history of psychology. To posit our ontological and epistemological perspectives, we then provide a detailed account of the principles of epistemological diversity, reflexivity, intersubjectivity, and situated and contextualized knowledge production as grounded on the critical approach and queer feminist science studies. Moreover, we underline the importance of holding these principles at the center of psychological studies. Afterward, we argue for a potential solution to methodological problems using multiple and mixed methods through a dialectical understanding and a critical approach framed by the suggested principles. Furthermore, we discuss the potential contributions of considering the issue of methodology from a critical perspective and approach it as a toolbox, in which one can find diverse methods and techniques to overcome the methodological problems of psychology. In doing so, we briefly introduce multiple and mixed methods and summarize the current discussions around the use of such methods in psychology. In summary, we argue that the contribution of psychology to solutions to societal problems can be enhanced using multiple and mixed methods from a critical perspective and the transformation of the existing literature. Within this framework, we propose that if the discussion begins with the basic principles required to construct a critical perspective (i.e., reflexivity, intersubjectivity, and situated knowledge), then questioning the purpose and the target of knowledge production instead of the type (i.e., qualitative or quantitative) of knowledge (and, consequently, the data) can become a more crucial basis of discussion.

Keywords: Methodological problems in psychology, scientific paradigms, qualitative and quantitative methods, critical approach, reflexivity, situated knowledge

\section{EXTENDED ABSTRACT}

Since the 19th century, different ontologies, epistemologies, and methodologies have emerged, and several heated discussions about methodology have continued following the proposition of Wilhelm Dilthey to distinguish between natural and human science. Conducting sociohistorical analysis by considering the relationship between human experience and the mind, Dilthey proposed a method of understanding for psychology (see Walsh, Teo, \& Baydala, 2014). However, the scientific attention on the individual and the singular was lost due to the dominant approach, which adopted Aristotelian physics in psychology. In addition, the non-repetitive was left outside of the conceivable of human psyche (Lewin, 1931). The futility of understanding the real, the unique, and the emotional received widespread acceptance, because the individual was positioned as the antithesis of law, such that qualitative traits were viewed as the exact opposite of the generality (Lewin, 1931). However, psychological phenomena are simultaneously unique and general not only because language brings together the singular and the general but also because the concept of individual, unique or personal is developed together with other people (Højholt \& Schraube, 2019; see also Teo, 2001).

As positivism became popular in the 19th century, the mutual and multifaceted relationship between human experience and the mind was overlooked. Scholars endorsed 
the dominant perspective, that is, the real world can be known objectively as natural facts; as such, scientific knowledge can be produced only through controlled experimentation and observation (Walsh et al., 2014). As a result, the deductive research methods of natural science captured the mainstream psychological tradition. Moreover, psychological science faced paramount problems related to its use of deductive methods through a single-sided and western-centrist perspective, which is based on the sole principle of falsifiability (see Holtz \& Monnerjahn, 2017). Recent solutions to these problems include open science practices and pre-registration (see Nosek et al., 2015). Although this understanding and its practice can reduce researcher bias, they are insufficient for the transformation of psychological science without a historical critique of psychology as a discipline.

Beyond this paradigm, we also need to conceive the role of intersubjectivity, which is a basic principle of critical epistemology, for acquiring psychological knowledge as part of empirical materials retracted from the experiences of researchers and the respondents as well as the relationships between them (Busch-Jensen \& Schraube, 2019). Accordingly, generalizations in psychological research should be related to the shared processes based on these forms of subjective experiences and actions in constant change. As such, researchers should include in their analyses the construction of meaning and its relations. This process requires a consideration of several crucial questions:

- "How does one reveal general relations based on the positioned/situated, intersubjective, and contextual qualities of the psychological phenomenon?"

- "What is the role of critique in the process of generalization?"

- "How does one include the subjectivity of the researcher and participants in the generalization?"

- "How does one develop analytical concepts and strategies for the conception of psychological phenomenon as a process and a movement?"

- "How does one reach psychological knowledge that is capable of transforming daily practices?"

\section{Discussion}

Generally based on the principles of intersubjectivity and reflexivity in critical theory and, specifically, driven by recent reflections on queer feminist science studies (Cipolla, Gupta, Rubin, \& Willey, 2017), this study posits that psychological science can approach the subject of research that it objectifies as a (simultaneously natural and cultural) "material-semiotic 
existence." Consistent with this approach, we can use different methods in a manner that seeks to understand the phenomenon being observed in its entirety and without hierarchical preference between methods. Toward this end, we propose the dialectical use of multiple paradigms and mixed methods that enhance our understanding of the phenomenon from diverse perspectives as a set of solutions for the general methodological problems observed in various fields of psychology (Greene \& Caracelli, 2003; Maxwell \& Loomis, 2003). If we rely on historical analysis, we can find that science progresses through the use of multiple methods.

It is suggested that a critical reflection on the issue of methodology, that is, approaching the problem with a toolbox, wherein one would find different methods and techniques, will help overcome the methodological problems in psychology. The contribution of psychology to the elimination of societal problems can be ensured by using multiple methods from a critical approach and by transforming the literature on psychology. Instead, of focusing on the type (i.e., qualitative or quantitative) of knowledge, questioning the purpose and the target of knowledge production based on the basic principles of critical theory (i.e., intersubjectivity, reflexivity, and situated/positioned knowledge) can become crucial bases of discussion. 
Doğa bilimlerinin tümdengelimci araştırma yöntemine teslim olan ana akım psikoloji geleneği (Teddlie ve Tashakkori, 2009; Walsh, Teo ve Baydala, 2014), tek taraflı ve Batı merkezci bir şekilde ve sadece yanlışlama ilkesi (bkz. Holtz ve Monnerjahn, 2017) temelinde tümdengelimci yöntemlerin kullanılması neticesinde bugün devasa sorunlarla karşı karşıya. Son dönemde tümdengelimci araştırmalarda nicel veri toplanması ve analiziyle ilişkilendirilen yanlılıklara dair yayınlar gitgide ilgi çekmeye ve tartışılmaya başladı (örn., Francis, 2012b; Ioannidis, 2005; Simons, Nelson ve Simonsohn, 2011). Yakın zamanda, örneğin dini inanç düzeyi ile şiddet içeren suçlar arasındaki ilişkinin IQ ile düzenlendiğini savunan bir makale, 1rksal eşitsizlikleri ve ölçümsel hataları göz önünde bulundurmadığı gerekçesiyle yayından geri çekildi (makaledeki ölçümsel hatalara işaret eden çalışma için bkz. Ebbesen, 2020). Bunun dışında, son yıllarda istatistiksel açıdan anlamlılık düzeyini gösteren $\mathrm{p}$ değerini ${ }^{1}$ belli bir düzeyde elde edebilmek için veriyi zorlama veya manipüle etme (p-hacking için bkz., Head, Holman, Lanfear, Kahn ve Jennions, 2015), hipotezleri analizlerden sonra yazma (harking), veri uydurma (örn., Stapel davası için bkz. Verfaellie ve McGwin, 2011), anlamlı çıkan bulguları yayınlama (publication bias, Rosenthal, 1979; daha güncel bir değerlendirme için bkz. Ferguson ve Brannick, 2012) gibi birçok sorundan bahsediliyor.

$\mathrm{Bu}$ ve benzeri sorunların kaynağı, istatistiksel yöntemlerin yanlı veya hatalı kullanıminda (Pashler ve Wagenmakers, 2012) aranabilir. Ne var ki, verinin çoğunlukla WEIRD $^{2}$ toplumlardan (Henrich, Heine ve Norenzayan, 2010) elde edildiği, araştırmalarda çoğunlukla kültüre özgülüklerin (emik-etik tartışması için bkz. Triandis ve Brislin, 1984) ve bağlamsal faktörlerin (bkz. Pettigrew, 2018) göz ardı edilebildiği, ırksal veya toplumsal cinsiyet ve cinsel yönelime dayalı eşitsizliklerin yok sayıldığı (Adams ve Salter, 2019, Gannon, Lucheta, Rhodes, Pardie ve Segrist, 1992; Herek, Kimmel, Amaro ve Melton, 1991), yapılan tekrar çalışmalarda yanlılıklar sergilenebildiği (replikasyonlar; Francis, 2012a) de göz önünde bulundurulduğunda, sorunun kaynağını sadece nicel (istatistiksel) yöntemlerin yanlı veya hatalı kullanımında aramak sınırlandırıcı ve yanıltıcı olacaktır. Buna ek olarak, bugünlerde daha fazla konuşulmaya başlanan açık bilim anlayışı (open science) ve önceden kayıtlama (pre-registration) ${ }^{3}$ gibi uygulamaların, veri

1 İlk kez Fisher'ın 1925 yılında yokluk hipotezi anlamlılık testi için keyfi bir şekilde .05 olarak belirlediği değer; ayrica bkz. Cohen, 1994.

2 Western, Educated, Industrialized, Rich, Democratic kelimelerinin baş harflerinin kısaltılması.

3 Bilimsel çalışmanın, örnekleminin, ölçümlerinin ve sayıltılarının çalışma öncesinde/sırasında veya sonrasında açıkça paylaşılması. 
üzerinde daha fazla 'kamusal' kontrol sağlayıp (Nosek ve ark., 2015) gözlenen araştırmacı yanlılıklarının azalmasına belli düzeyde katkıda bulunma olasılığı olsa da, bir bütün olarak psikoloji disiplininin tarihsel bir eleştirisi yapılmaksızın (istisnalar için bkz. Cushman, 1990; Gergen, 1973; Parker, 1990) bu tür girişimler de tek başlarına yetersiz kalabilirler.

Psikolojide istatistiksel prosedürlerin kullanımını eleştirenlerden biri olan Lewin (1931, s. 154), kullanılan istatistiksel yöntemlerin "zihinsel dünyanın tüm gerçekliğinin tam olarak anlaşılmasının başarılmasına işaret ettiği ölçüde meşru olduğundan" bahseder. Lewin (1931) için kritik olan, istatistiksel yöntemlerin psikolojide kullanımı değil, bunların nasıl kullanıldığı ve deney gruplarında kimlerin yer aldığıdır. Sorun, sosyal bilimsel araştırmaların güncel veya gelecekteki olaylara dair spekülasyon yapmak için tarihsel coğrafi somut veriye odaklanmasıdır (bkz. Dege, 2019). Herhangi bir psikolojik olguya dair gözlenen verinin ortalamasının alınmasını değil, içinde bulunduğu çağın kullandığ ${ }_{1}$ istatistiksel analiz tekniklerini eleştiren ve gelecekte istatistiksel tekniklerin gelişeceğini umut eden Lewin (1931), geçmişte elde edilen somut verinin geleceği anlamak için pek az şey ifade ettiğini belirtmişti.

Buradan yola çıarak ve güncel dünya yazınına dayanarak, biz bu yazıda, geleneksel ve ana akım psikolojinin yöntemlerine dair sorgulamalara ve başka türlü psikolojik bilgi üretmenin yollarına aralanan kapılara göz atmak istiyoruz. Daha belirgin olarak, sorunun kaynağının sadece istatistiksel yanlılıklarda değil ancak daha genel anlamda epistemolojik yaklaşımın kısıtllılığında (Meehl, 1997), bundan da öte, psikolojinin ontolojik ve epistemolojik pozisyonlanmasında aramamız gerektiğini düşünüyoruz. Doğa-kültür ikiliğinin zaman içinde yıkılmaya başlamasıyla insanın toplumsal davranışlarıyla ilgili daha karmaşık ama aynı zamanda daha bütüncül bilgiye erişme şansının yeniden yakalandığını, nitel-nicel ikiliğinin eleştirel yaklaşımın yöntemsel ilkelerine güvenilerek y1kılmasının mümkün olduğunu ve bugünün sorunlarını çözmede bu ikilikleri aşmanın yardımcı olabileceğini savunuyoruz. Tüm bu saydığımız nedenlerden ötürü, ana akım psikolojinin ontolojik ve epistemolojik pozisyonlanmalarına yönelik paradigmalara dair ilgili yazın temelinde psikoloji disiplinine tarihsel bir bakış atmak istiyoruz. Ardından, yöntem sorunlarının çözümüne dair dünya yazınında öne çıkan öneriler temelinde nasıl bir yaklaşım ve pratik oluşturabileceğimize dair fikirler sunacağız. 


\section{İnsan Zihni, Deneyimi, Bilimsel Paradigmalar ve Yöntem}

Psikolojinin felsefe ve tıptan koparak bağımsız bir bilim alanı olarak ortaya çıktığı yıllarda, bu alandaki araştırmacılar esas itibariyle doğa bilimlerine yönelmiş̧i (Mayring, 2002). İlk kurulan psikoloji kürsüleri ${ }^{4}$, insanların belirli testlere verdikleri tepkileri araştıran alg1 psikolojisi alanında çalışmalar yürütüyordu (örneğin Wilhelm Wundt'un 1879'da Leipzig'de kurduğu laboratuvar). Bu dönemde, psikolojide büyük ölçüde tümdengelimci yöntem benimsendi (Lewin, 1931). İnsanın anlama ve yorumlama etkinliğinden bağımsız bir gerçekliğin olduğu anlayışı, Tebes'in (2005) ifadesiyle zihinden bağımsız bir hakikat anlayışı, psikoloji alanında egemen oldu. Zihnin insan deneyimiyle ilişkisi ve dışarıdaki gerçekliğin anlama ve yorumlama yoluyla erişilebilir olduğu anlayışı terk edildi. Gerçek dünyanın nesnel bir şekilde bilinebileceği (facts) ve genel yasalara tabi olan gerçeklerin açıklanabileceği (pozitivizmin ${ }^{5}$ iki temel sayıltısı için bkz. Gjorgjioska ve Tomicic, 2019) aylayışı benimsendi. Bilimsel bilginin sadece kontrollü deney ve gözlem yoluyla üretilebileceği görüşü hâkim oldu ve diğer yöntemlerin gerçeğe dair geçerliliği reddedildi. Yirminci yüzyılın başlarında içebakış yöntemini reddeden ve gözlenen davranışlara odaklanan davranış̧̧ılık akımı, bu yüzyılın ikinci yarısından itibaren ise bilişsel deneycilik akımı ile psikoloji disiplininde (post)pozitivist paradigma egemen hale geldi (Ashworth, 2015; Howitt, 2010). Bu çalışmalar büyük ölçüde Amerika Birleşik Devletleri'nde (ABD) gerçekleştirilmişti ve oradan diğer ülkelere yayıldı. Bu şekilde psikolojideki 'Amerikanlaşma' (Metraux, 1985) uzun yıllar sürdü (Mayring, 2002) ve bir ölçüde sürmeye de devam ediyor ${ }^{6}$.

4 Psikoloji bilgisinin tohumları İngiltere, Fransa, Almanya ve ABD’de atıldı ki bu ülkelerin bazıları uzun yıllara yayılan sömürgeleştirme geleneğine sahipti (Walsh ve ark., 2014). O y1llarda, sömürgeci Avrupa ülkelerinde Darwin'in evrim görüşleri diğer toplumları aşağılamak için ideolojik bir araç haline getirilmişti (Richards, 2012). Bunun en iyi gözlendiği alanlardan biri ırk çalışmalarıdır. Örneğin, Francis Galton (1822-1911), Avrupalıların doğası gereği 'ilkel ırklardan' daha zeki olduğunu savunmuştu, nöropsikolojinin kurucusu kabul edilen Paul Broca (1824-1880) da Avrupalı olmayanların daha aşağı olduğunu ileri sürmüştü (bkz. Teo, 2011). Bu bakımdan, diğer bilim dallarında olduğu gibi psikoloji alanında da üretilen bilimsel bilgiler sömürgecilik döneminin egemen anlayışının izlerini taşıyor (bkz. Said, 1978). Bu yüzden psikoloji biliminin geçmişte olduğu gibi bugün de ürettiği bilgiye eleştirel açıdan yaklaşmak önem arz ediyor (ayrıca bkz. Bettache ve Chiu, 2019).

5 Pozitivist, post-pozitivist, sosyal inşacı, pragmatist ve dönüştürücü (transformative) paradigmaların ontoloji, epistemoloji, değerlerin rolü (axiology), nedensellik ve genellenebilirlik boyutları açısından karşılaştırılması için bkz. Guba ve Lincoln, 2005; Lincoln ve Guba, 1985; Teddlie ve Tashakkori, 2009. Ayrıca örneğin nitel araştırma geleneği içinde birbiriyle yarışan farklı paradigmalar için bkz. Guba ve Lincoln (1994).

6 Türkiye'de ilk psikoloji laboratuvarı 1915 yılında İstanbul Üniversitesi’nde Georg Anshütz tarafından kurulmuştu ve deneysel çalışmalar yürütülmüştü. Bu ilk yıllarda Avrupalı bir etki söz konusuyken, 1950'lerden itibaren 'hızlı' bir Amerikanlaşma yaşandı (bkz. Acar ve Şahin, 1990; Kağıtçıbaşı, 1994). ABD ve Avrupa psikoloji geleneklerinin örneğin tutumlar ve sosyal temsiller bağlamında karşılaştırılması için bkz. Howarth, 2006. 
Bu iki akım (davranışçılık ve bilişsel yaklaşımlar), erken dönem psikolojinin kullandığ 1 yorumsayıcı içebakış (interpretative introspective) yöntemlerinin 'bilim dışı' olarak etiketlenmesine yol açtı (Braun ve Clarke, 2013). Ne var ki, 1980'lerden itibaren nitel yaklaşımlar yeniden dayanak bulmaya başladı ('nitele dönüş' için bkz. Mayring, 1989) ve insan zihninden ve deneyiminden bağımsız (ve evrensel) gerçeklik anlayışı yeniden sorgulamaya açık hale getirildi (örn., Burr, 1995; Gergen, 1973, 1985, 1999; ayrıca 1950’li y1llarda pozitivizme getirilen eleştiriler için bkz. örn., Popper, 1959). Kita Avrupası'nda Spinoza'dan (1632-1677) Dilthey'e (1833-1911) uzanan hermönetik-fenomenolojist gelenek (Mayring, 2002) ABD’de yeniden keşfedildi (Banister, Burman, Parker, Taylor ve Tindall, 1994) ve bu gelişme bir süre sonra yankısını Kıta Avrupa’sında tekrar buldu (örn., Almanya için bkz. Witzel, 1982; Bergold ve Flick, 1987). Kişi ve bağlam, akışkan ve karşılıklı bir ilişki içinde (gerçekliği inşa eden ve gerçeklik tarafından inşa edilen insanın deneyimleri olarak) görülmeye (Braun ve Clarke, 2013); gerçeklik, onunla etkileşen insanın deneyiminin ve zihninin bir versiyonu olarak (relativizm) yeniden ele alınmaya başlandı ${ }^{7}$. Böylece, Kartezyen mantığın zihin/beden, ben/öteki, birey/toplum ikiliği (dualism) anlayışı gerilemeye başladı. Kartezyen mantık gereği zihin, uzun yıllar sadece bedenden değil, maddi ve sosyal dünyadan da bağımsız olarak ele alınmıştı (Farr, 1987). Aynı yıllarda, örneğin birey ve içinde yaşadığı toplum arasındaki karşılıklı ilişkiyi anlamayı zorlaştırmış Kartezyen ikiliğini aşan, sosyal temsiller kuramı (bkz. Moscovici, 1981) ve sosyal kimlik kuramı (Tajfel ve Turner, 1979) gibi sosyal psikolojik kuramlar ileri sürülmüştü.

İnsan deneyiminden bağımsız bir gerçeklik anlayışına (Kartezyen felsefe geleneğine), on yedinci yüzyılda bile karşı çıkan yazarlar vardı. Bunlardan biri olan Gianbattista Vico (1668-1744), dil ve davranış ilişkisinin Kartezyen açıklama ve kanıtlama ilkeleriyle ortaya çıkartılamayacağını ve pratiğin evrensel olamayacağını, çünkü deneyimin zamana ve mekâna özgü olduğunu ileri sürmüştü; aynı zamanda genel doğa yasalarının yerine belirli pratik kurallar arasındaki farklılı̆̆ı ortaya çıkarmaya çalışan, tarihsel, tekil yönelimli ve anlamacı tin bilimsel anlayışı ortaya atmıştı (Mayring, 2002).

7 Braun ve Clarke (2013), bir ayağını realizm bir ayağını da relativizm kutuplarına basan bağlamsalcılıktan (contextualisation) da ayrı bir epistemolojik yaklaşım olarak bahseder. Bu yaklaşıma göre, tek bir gerçeklik yoktur, bilgi belirli bir bağlam içinde ortaya çıktığından ve araștırmacının pozisyonunu yansıttı̆̆ından yerel, konumlandırılmış ve geçicidir. Her ne kadar gerçeği anlama çabası bulunsa da tek bir yöntemle bunun sağlanamayacağı düşünülmektedir (ayrıca bkz. Tebes, 2005). 
Bundan birkaç yüzyıl sonra bu ilişkileri sistematik bir şekilde irdeleyen ve tin bilimlerini (Geisteswissenscahften) doğa bilimlerinden (Naturwissenschaften) ayıran ${ }^{8}$ Wilhelm Dilthey, doğal ve zihinsel süreçlerin birbiriyle karşılaştırılamayacağını ve zihinsel yaşamın psikofiziksel bir bütün olan insanın görece bağımsız bir etkinliği olduğunu savunmuştu (Mayring, 2002; aynı zamanda bkz. Teo, 2001). İnsan deneyimini ve zihnini birbiriyle ilişkisi içinde ele alarak sosyotarihsel bir analiz ortaya koyan Dilthey’e (1922/2017) göre, isteme, arzulama, heyecan, duygulanma, amaç koyma, değer verme, değerlendirme ve benzeri zihin süreçleriyle donanımlı insanın tinsel dünyası, bilen öznenin psişik totalitesinde yer alır ve bilen insan, nesnenin (doğa da denebilir) karşısına psykhenin bu totalitesiyle çıkar. Hem başkalarından etkilenen hem de başkalarını etkileyen insanın deneyimi ve zihni arasındaki bu ilişkiyi (öznel zihin ile nesnel zihin ${ }^{9}$ arasındaki karşılıklı ve çok yönlü ilişki) ortaya koymak, tekilin nesnel kavranışından hareketle bağlantıları ve kapsamlı ilişkileri anlama yoluyla mümkün olabilir (Dilthey, 1922/2017). Böylelikle, Dilthey, gerçek dünyanın nesnel bilgisi yerine insan zihninin nesnelleştirilmiş ifadelerinin ortaya konabileceğini, yasalara tabi olan doğal gerçeklerin açıklanmasının yanı sıra hermenötik bir mantık vasıtasıyla insan eyleminin de anlaşılabileceğini savunmuştu. Ne var ki, pozitivizmin on dokuzuncu yüzyılda güç kazanmaya başlamasıyla birlikte tüm bu görüşler büyük ölçüde göz ardı edildi.

Sonraki yıllarda, Dilthey'in doğa ve tin bilimleri ayrımını benimseyen veya bu görüşe karşı çıkan bilim insanları oldu. Örneğin, Wilhelm Windelband doğa ve tin bilimleri sınıflamasını benimsemiş, genel yasaları (nomothetic) keşfetmeye çalışan doğa bilimle-

8 On dokuzuncu yüzyılda Dilthey tarafından ayrıştırılana dek bilim herhangi bir alanda üretilmiş bilgiler bütünü olarak görülüyordu (Walsh ve ark., 2014). Ne var ki Dilthey'in sınıflandırmasından sonra farklı ontolojiler, epistemolojiler ve metodolojiler ortaya çıktı (Bryman, 1984; Walsh ve ark., 2014) ve yöntembilim konusunda bugün hala tüketilmemiş olan tartışmaların fitili ateşlendi (ayrıca bkz. Gjorgjioska ve Tomicic, 2019).

9 Dilthey, öznel zihin ve nesnel zihin arasında karşılıklı ilişkinin tarihselliğinden bahsederek bu ikiliği reddeder. Marx ve Dilthey’in bu konudaki analizinin karşılaştırması için bkz. Teo (2001). Her ikisinin analizinde de zihin sosyo-tarihsel bağlamından koparılmadan ele alınır. Marx'ın nesnel zihin ve öznel zihin ve bunların birbiriyle ilişkisi anlayışına benzer biçimde, Dilthey de tüm bir çağın zihinsel oluşumunun tek bir bireyde temsil edildiğinden bahseder; Dilthey’e göre, insanın zihinsel etkinliği (fikirler ve kavramlar), maddi etkinliği ile iç içedir: İmgeleme, düşünme, ve insanların zihinsel etkileşimi maddi davranışın sonucudur; her iki fillozof da zihnin tarihsel ve sosyal olarak dolayımlanan içeriği ile ilgilenir ve zihni insan etkinliğine gömülü bir şekilde ele alır. Eş zamanlı olarak bireysel ve sosyal olan bu yaklaşım, Serge Moscovici'nin sosyal temsiller kuramında ve George Herbert Mead'in sosyal benlik kavramsallaştırmasında (bkz. Howarth, 2006) veya sosyal kimlik kuramında (bkz. Reicher, Spears ve Haslam, 2010) da görülebilir. Birey, sosyal çevresinin bir ürünüdür ve çevresini sürekli ve dinamik bir şekilde değiştirerek üretir. Ben/öteki, birey/toplum, birbirine aykırı olarak değil ancak bir aşkınlığa doğru birlikte çalışan iki tamamlayıcı birim olarak düşünülür. Bireyin düşünme süreci ve sosyal gerçeklik karşılıklı olarak birbirine bağlı ve dönüştürücüdür. Howarth'a (2006) göre, birey ve toplumun iki farklı nesne olarak kavramsallaştırılması kategorik bir hatadır, bunun yerine birbiriyle ilişki içinde var olan kurulumlar olarak ele alınmalıdır. 
ri ile tekil olayları (idiographic) ele alan tin bilimlerinin kullandığı yöntemlerin taban tabana zit olduğunu belirterek, ikincisinden yana bir tutum sergilemişti (bkz., Walsh ve ark., 2014). Buna karşın, psikolojinin doğa bilimi olduğunu ve bilimsel araştırmaların amacının açıklama olduğunu savunan, dolayısıyla psikolojinin temel yönteminin deney olması gerektiğini ileri süren psikologlar ön plandaydı (örn., Hermann Ebbinghaus ve Hugo Münsterberg; Walsh ve ark., 2014). Pozitivizm ve sonraki yıllarda da post-pozitivizm anlayışı, Dilthey ve Windelband gibi kişilerin düşüncelerinin psikoloji alanında etkili olmasını engelledi (Mayring, 2002).

Psikolojinin yöntem sorunlarının kaynağının, psikolojinin doğa bilimlerinin yöntemini olduğu gibi benimsemesi olduğunu ifade edenlerden biri de Kurt Lewin'di (18901947). Lewin'e (1931) göre, fiziksel doğanın yasaya tabi düzenliliği (Aristoteles'in fizik yasası) anlayışının psikolojide egemen olması neticesinde bireysel veya istisna olana yönelik bilimsel ilgi kaybolmuş, ‘tekrar etmeyen' kavranabilir alanın dışında bırakılmıştı. Belirli bir kişinin davranışından yola çıkarak yasaya ulaşma (lawfulness) sorunuyla karşı karşıya olunduğunu belirten Lewin (1931), bireysel olanın yasanın antitezi olarak görülmesi neticesinde araştırmanın sınırlandırıldığını ileri sürdü. Bu da gerçek, eşsiz, duygusal olanın veya belirli bir bireyin kişiliğinin yapısını anlamaya çalışmanın nafile olduğu kanısına yol açarak nitel özelliklerin genelin tam tersi olarak ele alınmasıyla sonuçlandı. Oysa genel olan tekil olanda gözlenebilirdi. Çünkü bireysel, eşsiz veya kişiye özgü olan, başkalarıyla birlikte geliştirildiğinden (insanın toplumsallığı için bkz. Teo, 2001), psikolojik olgu biricik olduğu gibi geneldir de (Højholt ve Schraube, 2019). Ayrıca, genel olana ulaşmanın (genellemenin) tek yolu, verinin istatistiksel olarak aritmetik ortalamasının alınması olmayabilir (bkz. Lewin, 1931). Bireyler tarafından geliştirilen genel özelliklerin tipler temelinde belirlenmesi (tekilleşme) ve bunların daha sonra soyutlanması yoluyla da genele ulaşılabilir (Dilthey, 1922/2017; soyutlama ve somutlama arasındaki ilişki için bkz. Holzkamp, 1973). Bir başka deyişle, anlama yöntemini benimseyen ve nitel veriyle görgül analiz gerçekleştiren araştırmacılar da genel olana ulaşabilir (ancak buradaki genelleme evrene yönelik değil örüntüyü ortaya çıkarmaya yönelik olur). Örneğin tematik analizde belirli temalar çıkarılırken bir yandan soyutlama bir yandan da ortak örüntüyü görmek amacıyla genelleme süreçleri işletilir (bkz. Braun ve Clarke, 2006; ayrıca, genel ve spesifik olan veya genellenen ve bireysel olan arasındaki ilişki için bkz. Teo, 2001). Belirli bir bağlamda ve durumda elde edinilen nitel bulguların başka durumlarda ve zamanlarda ne denli geçerli olacağ 1 ise tartışı- 
lır. Benzer şekilde, insan davranışları tarihsel etki altında, bağlama özgü ve öznel anlamlara sahip olduğundan, nicel çalışmalarda temsili örneklemin kullanılması -ki "temsili örnekleme hiçbir zaman tam olarak ulaşlamaz"- yoluyla evrene otomatik bir genelleme garanti edilemez (Mayring, 2002, s. 23).

Sonuç itibariyle, yöntemler arasında hiyerarşi kurmayarak ve belirli yöntemleri belirli alanların tekelinden çıkararak psikolojide epistemolojik çeşitlilik sağlanabilir. Nitel ve nicel araştırma yöntemleri tartışmasında yapılan ortak hataları tekrar etmemek adına, Shadish'i (1995) takiben, epistemolojik çeşitliliğin sağlanmasına yönelik savlarımızı şu şekilde sıralayabiliriz: İlk olarak, Galileo, Newton veya Muzaffer Şerif'in uyguladığ 1 üzere, deneyler de gözleme, nitel veriye ve sürece dayanabilir. Bu anlamda, sosyal bilimsel keşfin, olgusal gerçeğin (fact) keşfi değil, belirli bir bağlamda sınırlı bir müdahalenin ortaya çıkardığı sonuçlara dair kısıtlı bir keşif olabileceğini, yani her deneyin belirli bir bağlam içinde anlam ifade ettiğini benimsemeyi önemli görüyoruz. Ancak bu şekilde (fiziksel bilimlerde olduğu gibi) genel olarak sosyal bilimlerde, özel olarak da psikolojide deneysel yöntemi keşfetmek amacıyla da kullanabiliriz.

İkinci olarak, fiziksel olgular gibi sosyal olgular da çok boyutlu ve bağlamsal olduklarından, sosyal meselelere yönelik sosyal yapısalcılıkla donatılmıs fiziksel gerçeklik varsayımı yeni ve karma bilimsel yöntemleri ilerletebilir. $\mathrm{Bu}$ anlamda, deneycileri naif realistler veya naif pozitivistler olarak görmeksizin, naif realizmin uygulanabilirliğini sorgulamanın önemli olduğunu düşünüyoruz. Bir başka ifadeyle, birbirlerini karşılıklı ve dinamik olarak yeniden oluşturmaya devam eden sosyal yapılarla fiziksel gerçeklik arasındaki ilişkinin incelenmesi bilimsel olarak sürdürülebilir. Şöyle ki, ontolojik (gerçekte var olan) ve epistemolojik (neyin gerçekte olduğuna dair bilgi) realizm ayrımı üzerinden hareket edersek, deney (veya genel olarak bilim), varsayılan gerçekliğin özelliğinin belirlenmesi amacını (epistemolojik realizm) taşıyor. Öte yandan, dışsal gerçekliğin şu veya bu şekilde kanıtlanması zorluklar içeriyor çünkü gerçekliğin doğrudan algılanıp saf (başka gerçekliklerin karışmadığı) bir şekilde raporlanması ve kuramsallaştırılması tamamen mümkün olmuyor. Bu yüzden sosyal inşa (social construction) (lineer değil) dairesel geri besleme döngüleriyle ilerleyen sosyal gerçekliği anlamlandırmada elzem bir rol taşıyor (Gergen, 1999).

Üçüncü ve son olarak, bilimin toplum ve toplumsal değişim için ilerleyebilmesi açısından, sosyal gerçeklik arayışında farklı paradigmaları benimseyen kişilerin, bizlerin, 
epistemolojik şiddete (Teo, 2008, 2010, 2011) karşı temkinli, eleştiriye açık ve özeleştirel olması gerektiğini düşünüyoruz. Bu noktada, şunu tekrar vurgulamak isteriz: Deneycilerin pozitivist paradigmayı benimsemediği veya nicel veriyi kullanmadığ durumlar olduğu gibi (Shadish, 1995), nitel yöntemi benimseyen araştırmacılar da veriyi hem gerçekçi hem yorumcu paradigmalara (sosyal/psikolojik dünyayı açıklanabilir ve sistematik süreçlere bağlı görme, sosyal gerçekliği keşfetme/ortaya çıkarma veya deneyime dayalı aktarımların mevcut egemen yapıların yeniden ürettiği eşitsizlikleri gözler önüne serme amacı taşıma) dayanarak analiz edebilir (Willig, 2012). Kendi pozisyonumuzu daha iyi anlatabilmek için yönteme eleştirel açıdan yaklaştığımızda, diğer bir ifadeyle, eleştirel sosyal kuramsal yaklaşımın ilkelerinden yola çıktığımızda, neler gördüğümüzü aşağıda bazı yazınsal örnekler temelinde özetlemeye çalıştık.

\section{Yönteme Eleștirel Yaklaşım}

Yıllık Eleştirel Psikoloji Dergisi'nin (Annual Review of Critical Psychology) daha ilk sayısında, Ian Parker (1999) eleştirel psikolojinin tanımına ulaşabilmek için var olan farklı eğilimlerin kültürel-tarihsel bir hesabını yapmanın gereğinden bahseder. Psikoloji disiplini içindeki akademisyen, alanda çalışan uzman ve psikolojik danışmanlık alan kişi arasındaki sınırların sorgulanması kadar gerçekte eleştirel olan ile olmayan arasındaki sınırların da sorgulamasının önemini vurgular. Parker’a (1999) göre disiplin içindeki kavramların ve yaklaşımların tarihsel olarak nasıl üretildiğine duyarlı olan Eleştirel Psikoloji'nin aynı duyarlılığı 'alternatiflerin' sadece belirli bağlamlarda alternatif olabileceği konusuna da göstermesi gerekir. ‘Görelilik’ ve 'gerçekçilik' yaklaşımlarının farklı bağlamlarda farklı işlev gördüklerinden ve bunlardan birini 'radikal', diğerini ise 'muhafazakâr' olarak etiketlemenin yanıltıcı olduğundan söz eder. Örneğin, Güney Afrika'da fenomenoloji Aparteid rejimiyle işbirliğine dayalı acınacak bir tarihe sahipken, sosyal psikolojinin laboratuvar-deneysel yaklaşımı burada radikal bir kaynak olarak ortaya çıkmıştı. Latin Amerika'da yerli toplulukların psikoloji bilgisini üretmesini sağlayan sömürge karşıtı dini pedagoji yaklaşımı, özgürleşme psikolojisinin oluşmasını sağlamıştı. Hindistan'da ise radikal postmodern yaklaşımlar, baskıcı kültürel pratikleri sürdürmek için kullanılmıştı ve kullanılmaya da devam ediyor. Bundan yola çıkarak, eleştirel psikolojinin görevinin disiplin içindeki radikal bakış açılarını bir araya getirmek olduğunu belirten Parker (1999), eleştirel psikolojinin herhangi bir yaklaşımı diğerinden üstün tutmasını eleştirir. Ona göre radikal argümanların önünü kesmek için göreliliğge yaslananlar olduğu gibi, gerçeklik iddiasında bulunanlara karşı gerçekçilik üzerinden eleştiri getirmek mümkündür (ayrıca bkz. Parker, 2015). 
Bu görüşten hareketle, yöntem sorunları eleştirel bir yaklaşımla ele alındığında neler söylenebilir? Öncelikle, eleştirel sosyal kuramsal yaklaşımın ilkelerinden biri olan düşünümsellik (reflexivity), ana akım psikolojiyi yüzleşmeye ve değişime çağırabilecek elzem bir epistemolojik yaklaşım olabilir. Çünkü naif görgülcülüğün temel sorunlarından birinin 'hermenötik yitimi' olduğu savunulur ve bu sadece bir eksiklik olarak kalmaz, aynı zamanda 'epistemolojik şiddet' olarak karşımıza çıkar (Teo, 2011). Bilimin toplumdaki ayrıcalıklı otoritesi nedeniyle her türlü bilimsel yorumun özel bir statüye sahip olduğu ve bunun mevcut yapısal eşitsizlikleri ve şiddeti sürdürebileceği göz ardı edilir. Oysa bilim öyle bir otoritedir ki bilim insanı ‘ötekinin’ (genel olarak dezavantajlı konumda tutulan) politik ve ahlaki saikleri olduğunu ileri sürebilirken, kendisinin de aynı saiklere sahip olduğu savını kolayca reddedebilir (Teo, 2011). Düşünümsel yaklaŞım ise, araştırmacının araştırmacı olmasından dolayı sosyal güce sahip olduğunu, araştırma sürecinin tamamının ve araştırma sonrasında elde edilen bulguların ve çıkarımların yaratacağı değişikliklerin kendi güç konumundan etkilenebileceğini özeleştirel anlamda kabul etmesini ve bunu değiştirmeye yönelik hermenötik becerilerle kendisini donatmasını önerir. Düşünümsel yaklaşım, herhangi bir yöntemle kısıtlanamayacak kadar geniş, her yöntemde uygulanabilecek kadar nettir: Araştırmacının katılımcılara sunduğu seçenekleri şekillendirmede rolü vardır ve bu rol sebebiyle sınırdaki veya muhalif konumdaki öznellik şekillerinin bazılarını inkâr ya da ihmâl etme ihtimali bulunduğunu göz önünde bulundurmalıdır (Reicher, 1997).

Teo’nun (2008) önerdiği hermenötik işbirliği modeli, verinin çeşitli yorumlar geliştirmeye izin verdiğini ${ }^{10}$, araştırmacının dünya görüşünün yapılan yorumla bağlantılı (kuram, hem bilimsel bağlama hem de sosyo-tarihsel bir bağlama sahiptir) olduğunu görmemizi sağlar. Hermenötik işbirliği modeline göre çalışmayı yürüten araştırmacı(lar) veriyi elde ederken, diğer araştırmacılar veri hakkında yorumlarda bulunurlar, bulguları tartışırlar. Bu sayede, görgül araştırmanın sadece hipotez geliştirip kuramın test edilmesinden ibaret bir süreç gibi anlaşılmasına yol açan, verinin tartışılması aşamasında yorumun etkisini reddeden ve değer-tarafsızlı̆̆ı (fact versus value) anlayışını savunan, böylece kuram-veri-tartışma arasındaki ilişkiyi koparan pozitivizmin epistemolojik şiddetinin (Teo, 2008, 2010) önüne geçmek mümkün olabilir (ayrıca bkz. Teo, 2011).

10 Belirli bir deneysel savın nasıl yorumlanacağıyla ilgili yöntemsel bir ilke veya belirli bir kuramsal yorumun geçerli olmasını sağlayan herhangi bir kriter yoktur, nitekim çeşitli kuramsal savlar çeşitli deneysel desenlere olanak verir, dolayısıyla hem kuramsal savlar hem de deneysel savlar belirli bir derecede keyfidir; her deneysel savın sonsuz kuramsal anlamı olabilir (Teo, 2011). 
Bunun yanında, Teo'ya (2011) göre hermenötiğin geçerliği ve güvenirliği için kriterler geliştirilerek bir kılavuz oluşturulmalı ve araştırmacılar hermenötik becerilerle (yorumun sonuçları hakkında düşünme) donanmalıdır. Bu iki şekilde sağlanabilir: a) kavramın ele alınışı kuramsal olduğu kadar tarihsel olarak da konumlandırılarak sorgulandığında, b) tartışma sonunda önerilerde bulunurken kimlerin ('ötekinin’) ne şekilde zarar görebileceği göz önünde bulundurulduğunda.

Benzer bir görüşle Reicher (1997), düşünümsel yaklaşımın hem deneysel hem de söylemsel veya betimsel araştırmada benimsenebileceğini savunur ve birçok çalışmasında bu savunusunu uygular. Böylesi bir çabaya çeşitli yöntem arayışları olan feminist psikoloji alanında da rastlanabilir. Feminist psikoloji alanında bir taraftan düşünümsellik diğer taraftan yöntemsel çeşitlilik ve aynı zamanda feminist politik gayeler, epistemolojinin ve bilimsel alana dair katı yaklaşımların önündedir. Öte yandan, düşünümselliğin nitel araştırmacılar tarafindan da yeterince uygulanmadığ 1 durumlar görülebilir. Örneğin Clarke ve Braun (2019), feminist psikoloji alanındaki iki dergide yayınlanan çalışmaları taradıkları ${ }^{11}$ yazıda, düşünümsellik ilkesinin ve yazarın (kuramsal ve politik) pozisyonlanmasının araştırmalarda, analizlerde ve makale yazımında yeterince uygulanmadığını, bunun yerine, nitel analizin 'yansız' ve salt 'betimsel' olarak konumlandırıldığını belirtir. Clarke ve Braun’a (2019) göre düşünümselliğin yeterince uygulanmaması, araştırmacının kendisinden 'farklı' olanlarla araştırma yaparken yorumlarını yansız ve kesin doğrular şeklinde konumlandırmasına, üretilen bilginin üretim sürecinin sorumluluğunu üstlenmemesine yol açar ve nihayetinde 'ötekinin temsilini' riske atar. Bu durumda, düşünümsellik aynı zamanda belirli bir bağlamda insan ve eylem arasındaki ilişkiye dahil olan hatta bu ilişkiyi belirleyen güç etkenlerinin ve eksenlerinin hesaba katılmasını gerektirir. Böylece alana dair sorgulamalar eşliğinde araştırma yöntemi belirlenirken, bir araştırma yönteminin tamamen gözden çıkarılmasından ziyade alet çantasında bulunan her araştırma yönteminde düşünümsel yaklaşım benimsenerek yöntemler toplumsal değişime destek olacak şekilde dönüştürülebilir.

Højholt ve Schraube'ın (2019) belirttiği gibi, insanın öznelliği, bireyin içinde olan bir şey değil, bireyin deneyimini, eylemini, gündelik hayattaki kolektif katılımını algılamasıyla, biçimlendirmesiyle, sosyal ve maddi koşulları değiştirmesiyle ilintili bir durumdur. Gündelik yaşam, farklılıkları, çatışmaları ve değişimleri kapsar ve bunlar

11 Çalışmada, Feminism and Psychology ve Psychology of Women Quarterly dergilerinde 2005 ile 2016 arasında yayınlanmış ve nitel yöntemlerle yapılmış araştırmalar taranmıştır. 
üzerinden gelişir. Farklı pozisyonlardan kişiler, farklı sorumluluklara, probleme dair farklı bilgilere, çok yönlü amaçlara ve kaygılarla sahiptirler. Bu durum, araştırmacılar ve araştırmanın katılımcıları için de geçerlidir. Dolayısıyla, eleştirel epistemolojinin temel ilkelerinden bir diğeri olan öznelerarasıllığın (intersubjectivity) psikolojik bilgiyi sağlamadaki rolü, araştırmacı ve katılımcıların öznel deneyimlerinin ve bunlar arasındaki ilişkilerin elde edilen görgül materyalin bir parçası olduğu görülmeli (Busch-Jensen ve Schraube, 2019).

$\mathrm{Bu}$ açıdan, psikoloji araştırmalarındaki genellemenin sürekli bir değişim içinde bulunan bu türden belirli öznel deneyimlere ve eylemlere dayanan ortak süreçlerle ilintili olması gerektiğini düşünüyor ve araştırmacıların, anlamın kurulumunu ve bağlantılarını analize katmaktan geri durmamasını öneriyoruz. Psikolojik olgunun konumlandırılmış, öznelerarası ve bağlamsal özellikleri üzerinden genel bağlantıların nasıl ortaya çıkarılacağına, genellemede eleştirinin rolünün ne olacağına, genellemeye araştırmacının ve katılımcının öznelliğinin sistematik bir şekilde nasıl dâhil edileceğine, psikolojik olgunun süreç ve hareket olarak kavranmasında analitik kavramların ve stratejilerin nasıl geliştirileceğine ve gündelik pratiği dönüştürecek olan psikolojik bilginin nasıl elde edileceğine yönelik soruları, eleştirel bir genelleme açısından üzerinde durulması elzem sorular olarak görüyoruz.

Bilimi dışsal bir gerçekliğin nesnel bilgisi şeklinde ele alarak bizi özne-nesne ikiliğine hapseden geleneksel fikirleri eleştiren kuir feminist araştırmacılar (Cipolla, Gupta, Rubin ve Willey, 2017; Roy ve Subramaniam, 2016), bilimin eş zamanlı olarak hem maddesel, hem bağlamsal, hem de söylemsel olduğunu belirtir ve genelde maddeselliğin, daha özeldeyse bilimsel bilgilerin 'konumlandırılmış' ('situated') olarak ele alınması gerektiğini ileri sürerler. Örneğin, Roy ve Subramaniam'a (2016) göre, bilim ve araştırdığını iddia ettiği nesnel doğa, anlamın ve öznelliğin sosyokültürel ve politik alanları göz önünde bulundurulmaksızın bağlamsızlaştırıldığından, 'doğa ve kültür' benzeri ikilik sorunları karşımıza çıkar. Oysa bilimsel araştırmaların pratikleri, kullanılan teknolojiler ve bulguları tanımlamak ve açıklamak için kullanılan dil ve araştırmanın bağlamı, bilimin aynı zamanda sosyokültürel bir eser olarak oluşmasını sağlar. Diğer taraftan, dünyanın basit bir biçimde kültürel veya dilbilimsel bir inşa olduğu anlayışına da karşı çıkan güncel kuir feminist bilim çalışmaları, cinsiyetçilik ve ırkçılık gibi birikimsel tahakkümlerin fizyolojik etkileri söz konusu olduğundan hem yerelde hem de dünya genelinde politik olanın maddesel olana, yani bedenlerimize kazındığını savunur 
(Roy ve Subramaniam, 2016). Bu temelde, kuir feminist epistemolojiyle çalışmalarını yürüten araştırmacılar, bilimsel bilginin ve maddeselliğin tarifini, birbirini besleyerek oluşturan güç ve ayrıcalık süreçlerini ortaya koyacak şekilde geliştirebilmek için 'doğakültür' benzeri ikilikleri yapısöküme uğratarak ortadan kaldırmaya ihtiyacımız olduğunu savunur (Roy ve Subramaniam, 2016).

Bunu yaparken bilim karşıtı bir pozisyonu benimsemeyen ve kuir feminist bilim çalışmaları sürdürenler, geleneksel bilimin egemenlik rejimlerini ve nesnellik illüzyonları$\mathrm{n} 1$ yeniden üretmeyen yeni ve güncellenmiş bilimsel praksislere ulaşılabileceğini ileri sürerler (Cipolla ve ark., 2017). Bilginin üretimine ilişkin şartların belirli çalışma nesnelerinin kavramsallaştırılmasını nasıl etkilediğini düşünümsel olarak kabul etme konusunda geleneksel bilgi üretiminden ayrılırlar. Olgunun farklı yerlerde farklı şekillerde ortaya çıkabileceği kabul edilir. Konumlandırılmış ve bağlamlandırılmış bilgi, gördüğümüz şeyi görmeyi nasıl öğrendiğimizle, gördüğümüz şeyin maddesel ve politik anlamda 'bedenleşme'sine (embodiment; Willey, 2016) ilişkin eleştirel düşünmemizle, buna dair aldığımız etik pozisyonlarla ve eylemlerin sorumluluğuyla ilintilidir. Bu açıdan, ataerkil, Hetero/Cisnormatif, Sağlamc1, Beyaz ve Batı egemenliğine dayanan bilimsel bilginin karşısında madun grupların bilimsel bilgisi konumlandırılabilir. Öte yandan, konumlandırılmış ve bağlamlandırılmış bilgilerin çokluğu hem görelilik hem de tekçilik karşısında bir hısım olarak belirse de, yine bağlamları ve bilgi üreticilerin konumlandıkları yerler itibariyle bu bilgiler önyargılardan ve güç ilişkilerinden muaf olmadıkları için çoğu zaman 'masum' değillerdir. Fakat bask1, unutma ve yok etme yöntemiyle inkâr hallerinin geçmiş bilgisine sahip olunarak oluşturulan bu konumlandırılmış ve bağlamlandırılmış bilgiler, her tür bilginin eleştirel ve tabirsel çekirdeğinin inkârına en az geçit verme ihtimaline sahiptir. Kısaca, kuir feminist bilim çalışmalarında bilimsel araştırmalara dair birbiriyle ilişkili iki noktanın önemi vurgulanır: 'Doğa-kültür' ve benzeri yapay ayrımları aşmak ve modern bilimin sözde nesnel bilgisi iddiasına karşın, bunun 'konumlandırılmış’ ve 'bağlamlandırılmış’ bilgi olduğunu kabul etmek.

\section{Örnekler ve Öneriler}

Psikoloji alanında gerçekleştirilen araştırmaların bulgularına eleştirel bir şekilde yaklaştığımızda hem doğa-kültür ikiliği hem de yöntem ikiliği ayrımını aşmanın mümkün olduğunu görebiliriz. Örneğin, zihin gibi ağırlıklı olarak doğa bilimleri yönteminin kullanıldığı çalışmalar, anlam üzerine odaklanan araştırmaların bulgularıyla bir araya getirildiğinde zihin olgusunu daha bütünlüklü bir şekilde anlayabiliriz. Bu çerçevede, 
örneğin Willey'in (2016) ileri sürdüğü gibi zihnin gerçek veya maddi bir varoluşunun olduğunu (beyin, sinir sistemi vb.) ve bu varoluşun karmaşık bir sistem içerisinde (kimyasal, fizyolojik, kültürel, politik) insan zihnini ve deneyimini (psikolojinin popüler ifadesiyle davranışı) ürettiğini söylemek mümkün. ${ }^{12}$ Diğer bir ifadeyle, psikofiziksel bir bütün olan insan, tarihsel olarak ve deneyim farkl1l1klar $1^{13}$ vasıtasıyla tekilleşir (bkz. Dilthey, 1922/2017). Böylece örneğin tüm genel ve ortak süreçlere rağmen herkeste aynı düşünce (kategorinin içeriği de denebilir) ortaya çıkmayabilir (bkz. Churchland, 2019). Bunda, kültürün de etkisi bulunur (kültürel psikoloji için bkz. Cohen ve Kitayama, 2019). Kültür, zihnin içeriğini farklı şekillerde etkiler ve ondan etkilenir (Markus ve Hamedani, 2019). Kültürel değerler ve pratiklerden etkilenen algı, hafiza ve kavramsal yapılandırma alanlarında bu daha da net görülür (örn., Astuti, Solomon ve Carey, 2004). Sosyoekolojik bir yaklaşıma sahip olan kültürel sinirbilim (Kitayama, Varnum ve Salvador, 2019), bilişsel süreçlerin nöral elementlerini (substrates) bir çeşit salt ekolojik vakum içinde belirlemeye çalışan nörobiyolojinin nörotipik, indirgemeci ve (tüm evrene) genellemeci eğiliminin ötesine geçer (Henningsen ve Kirmayer, 2000). İnsanın beyninin olduğu kadar davranışının da genler ve çevre (kültür ve deneyimler de dahil olmak üzere) arasındaki karmaşı etkileşimler etkileşimlere açık olduğunu ileri sürer (Zelazo ve Paus, 2010). Dolayısıyla, insan davranışını ve kişiliğini ne tek başına doğa (doğuştan gelen) ne de tek başına çevre (sonradan edinilen) açıklayabilir; ancak bu ikisinin etkileşimiyle davranış ve kişilik biçimlenir. Nitekim Lewin (1939) de uzun yıllar önce davranışın kişi ve kişinin içinde bulunduğu çevrenin bir fonksiyonu olduğunu ileri sürmüştü.

Doğa-kültür, nicel-nitel gibi ikiliklerin aşılmasına ve 'ötekinin yararına' (Teo, 2011) olabilecek araştırmaların yapılmasına dair örnekler çoğaltılabilir. Örneğin, neoliberalizmin insanların gündelik yaşamlarında ne derece gözlenebilir olduğuna yönelik yapılan nicel çalışmalar, insanların neoliberalizmi ne derece meşrulaştırılabildiklerine dair önemli bulgular sağlıyor (Beattie, Bettache ve Chong, 2019; Dutt ve Kohfeldt, 2019; Hartwich ve Becker, 2019; Panno, Leone ve Carrus, 2019). Aynı şekilde, toplumsal cinsiyet eşitsizliği konusunda yapılan deneysel araştırmalar (örn., Subasic ve ark., 2018), problemi betimlemenin ötesine geçilerek yeni bir praksisin ortaya konmasına katkıda

12 Engels (1876-78/1977, s. 93), bu konuda şunları söyler: "Düşünce ve bilincin ne oldukları ve nereden geldikleri sorulursa, bunların, insan beyninin ürünü oldukları ve insanın da doğanın çevresi içinde ve çevresi ile birlikte gelişen bir üründen başka bir şey olmadı̆̆ı görülür".

13 Dilthey’e göre bireysel farklılıklar “iş bölümü ve sosyo-politik farklılaşma tarafindan belirlenir" (bkz. Teo, 2001, s. 205). 
bulunabilir. Burada, eleştirel bakış açısını uygulamanın yolunun, belirli bir yöntemi kullanmaktan ya da verinin nicel veya nitel olmasından ziyade, Walsh ve arkadaşlarının (2014) belirttiği gibi, eleştirel düşünce için gerekli olan şu soruların sorulup sorulmad1ğıla ilintili olduğunu belirtmekle yetinilebilir: Kuramların, yöntemlerin ve analizlerin anlamı ne? Bilim insanı veya araştırmacı neden belirli bir iddiayı ortaya atıyor? Bu iddianın dışsal (şirketler, hükümet, diğer kurumlar, ideolojiler vb.) çıkarlarla ilişkisi ne? Araştırmacı ortaya attığı iddiayı nasıl yorumluyor? Araştırmanın sonuçları bireyleri ve toplumu nasıl etkileyebilir, araştırmanın sosyal eylem için (etik-pratik) anlamı nedir?

Genel anlamda eleştirel kuramın düşünümsellik ve öznelerarasılık ilkelerinden, daha belirgin olarak da kuir feminist bilim çalışmalarının güncellenmiş önermelerinden (Cipolla ve ark., 2017; Roy ve Subramaniam, 2016; Willey, 2016) yola çıkarak, psikolojinin araştırdığı ve böylece nesneleştirdiği konuya 'maddi-göstergesel varlık' (eş zamanlı olarak doğal ve kültürel) şeklinde yaklaşmasının mümkün olduğunu savunuyoruz. $\mathrm{Bu}$ yaklaşımla tutarlı olacak şekilde, herhangi bir yöntemi diğerinden üstün tutmadan, olguyu kendi bütünlügü içinde anlamaya katkıda bulunacak şekilde çoklu ve karma yöntemlerin kullanılmasının önemini vurgulamak istiyoruz. Nitekim tarihsel bir değerlendirme yaparsak, bilimin aslında çoklu yöntemleri kullanarak ilerlediği görülebilir. Öyle ki doğa bilimleri (özellikle fizik ve biyoloji) dahi, sanıldığının aksine sadece tümdengelimci yönteme dayanmıyor; tümevarımcı yöntem (gözleme dayalı verilerin akıl yürütme yoluyla yorumlanması, başka bir anlatımla, bir olgunun ortaya çıktı̆̆ı görüngülerin gözlenmesinden yola çıkarak, nedenlere ve görüngüler arasındaki ilişkiler örüntüsüne dair soyutlama yapmak) de kullanılıyor. Örneğin, antik dönemde tümevarımcı, karanlık dönemde tümdengelimci, Rönesans'ta çoğunlukla ama on sekizinci yüzyılda tamamen tümevarımcı, on dokuzuncu yüzyılda her ikisi arasında dengede, yirminci yüzyılın ilk yarısından bu yana ise tamamen tümdengelimci bir yöntem anlayışı doğa bilimlerine damgasını vurmuş (Belozerov 2002; akt., Teddlie ve Tashakkori, 2009). Benzer şekilde, tin bilimleri alanında (günümüzün sosyal bilimleri için de geçerli) ${ }^{14}$ her iki yöntemin birlikte kullanıldığı zamanlar olduğu gibi, birinin diğerine kıyasla baskın olarak benimsendiği dönemler de var. Mesela antik Yunan döneminde başlangıçta tümdengelimci, sonrasında tümevarımcı bir yaklaşım benimsenmişti, hatta Aristoteles önce tümdengelimci analitik yaklaşımı, sonraki yıllarda tümevarımcı yaklaşımı benimsenmişti (Teddlie ve Tashakkori, 2009).

14 Yazının önceki bölümlerinde anlatıldı̆̆ı gibi, doğa ve tin bilimleri ayrımı Wilhelm Dilthey tarafından yapılmıştır. Günümüzde tin bilimleri yerine sosyal bilimler yaygın olarak kullanılmaktadır. 
Psikoloji alanında da böylesi güncel eleştirel yaklaşımların çok da uzağına düşmeyen ilkeler uzun zaman önce benimsenmiş ve uygulanmıştı. Örneğin, Kurt Lewin bir yandan fenonemolojik yaklaşımı, bir yandan sosyolojik meta-kuramsal yaklaşımı, bir yandan görgül ve matematiksel yaklaşımı ve uygulamalı psikoloji anlayışını araştırmalarında kullanmıştı (bkz. Dege, 2019). Biliş, duygu, davranış arasındaki veya nöral olanla kültürel ve sosyal olan arasındaki ilişkilerin anlaşılması, insanın çok boyutlu ve bütüncül bir anlayışla ele alınmasıyla ve buna uygun çoklu yöntemsel yaklaşımların benimsenmesiyle mümkün. Geleneksel araştırma yöntemlerinden farklı olarak çoklu analiz düzeylerinde ölçüm alındığından (örneğin nöral düzeydeki veri, sözel ve sözel olmayan davranışlardan elde edilen verilerle birlikte değerlendirildiğinde; Zelazo ve Paus, 2010), önceden tasarlanmışı dayatmak yerine, deneyimleneni de görmek ve yaşantıyı dönüştürmek (Lefebvre, 1981/2010) daha olasıdır.

Bu noktada, farklı psikoloji alanlarındaki genel yöntem sorununa olası bir çözüm seti olarak olguyu çeşitli açılardan daha iyi anlamamızı sağlayan çoklu paradigmaların ${ }^{15}$ ve karma yaklaşımların diyalektik bir şekilde kullanılmasını öneriyoruz (Greene ve Caracelli, 1997a; 1997b; 2003; Maxwell ve Loomis, 2003). Çoklu ve karma araştırma yöntemlerine yönelik bilimsel anlatılar zaman zaman birbirine karışsa da ikisi arasında bazı farkl111klar bulunuyor (Anguera, Blanco-Villaseñor, Losada, Sánchez-Algarra ve Onwuegbuzie, 2018). Örneğin, bir çalışmada birden fazla nitel ya da birden fazla nicel yöntemin kullanılması o çalışmanın çoklu yöntem kullandığını ortaya koymakta yeterli görülebilir (Creswell ve Plano Clark, 2007). Buna karşın, karma yöntem ${ }^{16}$ araştırmalarında hem nitel hem de nicel yöntemlerin belirli bir sırada veya eşzamanlı olarak kullanılması beklenir. İkincisi, çoklu araştırma yöntemlerinde bir araştırma dahilinde kullanılan iki veya daha fazla yöntemin aynı amaca erişmek için birlikte kullanılması zorunlu görülmez, araştırmanın alt sorularına göre farklı yöntemlerin kullanılıyor olmas1 yeterli sayılır. Karma araştırma yöntemlerinde ise nitel ve nicel araştırma yöntemleri-

15 Greene ve Caracelli’ye (2003) göre mesele, tarihsel olarak farklı paradigmaların birbirine tezat varsayımlarının ötesine geçer; araştırmacının değerleri olduğunu düşünme-bunu reddetme, emik-etik yaklaşım, tekillikgenelleme, sosyal kurulum-fiziksel alt yapı gibi ikilikler önem kazanır, dolayısıyla yazarlara göre çoklu yöntemleri kullanmak makul bir yaklaşımdır.

16 Karma yöntemler, farklı desenlere sahip olabilir. Örneğin Creswell ve Plano Clark (2007), ardışık açıklayıcı (tümdengelimli mantığa dayalı olarak önce nicel ardından nitel çalışmanın yapıldığı), ardışık keşfedici (tümevarımlı mantığa dayalı olarak önce nitel ardından nicel çalışmanın yapıldığı), ardışık dönüştürücü (herhangi bir yorum yapılmadan evvel belirli bir kuram temelinde nitel/nicel çalışmanın veri beslemesiyle nicel/nitel ikinci çalışmanın belirlenmesi üzerinden), eşzamanlı triangülasyon (nitel ve nicel yöntemlerin karşılaştırmalı olarak kullanıldı̆̆ı), eşzamanlı yuvalama ve eş zamanlı dönüştürücü desenlerden bahsederler. 
nin araştırma sorularına ve amacına uygun şekilde birbirleriyle bütünleştirilerek kullanılması, yani aynı soruyu cevaplamak için beraber kullanılması ön plana çıkar (Hesse-Biber, 2015). Hem çoklu hem de karma araştırma yöntemleri, nitel araştırmalarda veriyi betimlemenin ötesine geçilip birçok açıdan yorum yapılabilmesine, nicel araştırmalarda ise verinin bağlı olduğu bağlamın ve koşulların anlamlandırılabilmesine yardimcı olur.

Öte yandan, araştırma yöntemine sadece teknik bir mesele olarak yaklaşılması, karma yöntemlerin besleneceği bilimsel paradigmaların nasıl uzlaşacağ1 veya çarpışacağ1 sorusunu gölgeleyebilir. Bu nedenle bu yazıda bir yöntemi diğerine üstün tutmadan tüm yöntemleri özgürleşmeci bir gaye için alet çantasında bulundurmanın önemi üzerinde duruyoruz. Teo'nun (1999) betimlediği şekilde ifade edersek, çeşitli yöntemleri özgürleşmeci pratik bir gaye temelinde kullanabiliriz. Bunun için önce toplumsal yapılara içkin olan tahakküm eksenlerini (1rk, cinsiyet, toplumsal cinsiyet, sınıf, yaş, sağlamlılık vb.) yapısöküme uğratmak (deconstruct), ardından bu dinamiği psikolojinin mevcut işlevindeki rollerini ortaya çıkararak tarihsel veya güncel olarak yeniden kurgulamak (reconstruct), ve nihayetinde 1 rkçılık, cinsiyetçilik, sömürü ve istismar süreçlerini eleştirel bir perspektifle yeniden ele alacak kuramlar, yöntemler ve kavramlar kurmak (construct) için çaba gösterebiliriz. Özellikle son dönemde yöntem krizini deneyimleyen ve temelde pozitivist yöntem eğitiminden geçmiş fakat araştırma ve eğitim hayatlarının bir yerinde eleştirel epistemolojinin sosyal bilimler açısından önemini fark etmiş birçok araştırmacının benzer duruşlar ortaya koymaya çalıştığını ve bunun için araştırmaya, yazmaya ve özeleştiriye devam ettiğini görmek de mümkün. Örneğin Hope, Brugh ve Nance (2019), eleştirel epistemolojinin araştırmacının araştırmaya ilişsin güç statüsünü sorgulaması ve araştırma süreçlerine dair karar süreçlerini arşivleyerek yapısal eşitsizliklerin yeniden üretilmesine karşı hazırlıklı olması yoluyla psikoloji alanındaki nicel çalışmalarda da uygulanabileceğini belirtiyor .

Günümüzde çoklu ve karma yöntemlerin kullanılmasına dair çeşitli görüşler savunuluyor (1990'lı yılların ortasından itibaren bilimdeki paradigma tartışmaları azalmıştır; bkz. Patton, 2002). Farklı yaklaşımların dayandıkları paradigmaların birbirine tezat teşkil ettiğini, bu sebeple bu yöntemlerin bir araya getirilemeyeceğini ileri süren araştırmacıların (örn., Guba, 1987; Sale, Lohfeld ve Brazil, 2002; Smith, 1983) yanında, bu paradigmaların uyuştuğu (compatibility) tezini öne çıkaran (bkz. Teddlie ve Tashakkori, 2009) ve çoklu yöntemlerin kullanılmasından yana olan nitel araştırmacılar (örn., Den- 
zin ve Lincoln, 2005) veya karma yöntem savunucuları (örn., Creswell, Plano-Clark, Gutmann ve Hanson, 2003; Creswell, 2003; Teddlie ve Tashakkori, 2009) da bulunuyor. Bu noktada, çoklu ve karma yöntemlerin kullanımındaki temel ilkenin eklektik değil diyalektik olduğunu hatırlamakta fayda olabilir. Yukarıdan aşağıya (tümdengelim) ve aşağıdan yukarıya (tümevarım) araştırma süreçleri (dışaçekimsel/geriçıkarımsal yaklaşım için örn., bkz. Reichertz, 2010) ile nitel ve nicel araştırma yöntemleri ancak diyalektik bir bütünlük içinde ve mevcut sosyal yapılardaki tahakküm dinamiklerini ortaya çıkarıp sosyal ve yapısal eşitsizliklere karşı topluluklarla dönüştürücü ve güçlendirici faaliyetler kurgulamaya yönelik olarak ele alındığında bilimsel faaliyetin doygunluğa erişme imkanı olur. Dolayısıyla buradaki yaklaşım, kuramsal ya da uygulamaya yönelik herhangi bir dayanağı olmaksızın, araştırmacının işine geldiği gibi yöntemleri birleştirmeye çalışması (pratik pragmatizm) değildir. Tam tersine, araştırmacı bu anlayışa set çekerken, araştırma sorusuna en uygun yöntemlerle yanıt aramaya çalışabilir (felsefi pragmatizm; Hesse-Biber, 2015). Bunu yaparken, nitel ve nicel araştırma yöntemlerinin farklı bilim paradigmalarından, ayrıca kavramsal, normatif ve etik açılardan farklı felsefelerden beslendiklerini araştırma sürecinin tamamında göz önünde bulundurmalı (Hesse-Biber, 2015).

Uzun yıllar pozitivizmin etkisi altında kalan psikoloji alanında çoklu ve karma yöntem kullanımının örnekleri artık daha sık karşımıza çıkıyor. Nitel araştırma yöntemlerinin bilimselliğinin sorgulandığı zamanlar yavaş yavaş geride kalıyor ve araştırmanın amacının ve sorusunun hangi yöntemin kullanılacağını belirleyeceği yönündeki tutumlar yaygınlaşmaya başlıyor (örn., Teddlie ve Tashakkori, 2009). İnsan duygularını, bilişlerini ve davranışlarını birey ve topluluk temelinde anlamaya odaklanan bir bilim alanı olarak psikoloji araştırmalarında çoklu ve karma yöntemleri kullanan bilim insanlarının sayısı artıyor. Çoklu ve karma yöntemler, gerek sosyal bilimlerin içinde gerekse sosyal ve doğa bilimleri arasındaki sınırları aşmaya odaklanan disiplinler ötesi çalışmalarda daha fazla kullanılıyor. Tüm bu gelişmeler, mevcut bilgi üretimi düzenlerine eleştirel bakışı daha da mümkün kılıyor. Bir başka ifadeyle, araştırma yöntemlerinde bilim insanın 'alet çantası' metaforu (Reicher, 1997) daha fazla karşılık buluyor. Bir taraftan veri toplama ve analizine yönelik tümdengelim ve tümevarım yaklaşımlarını, diğer taraftan da nitel ve nicel yöntemleri birbirini tamamlayacak araştırma süreçleri olarak kullanmanın gereği daha fazla anlaşılıyor. Örneğin grup kategorileme ve gruba aidiyet süreçlerinde hem tümevarım hem de tümdengelim ilkelerini benimseyen (bkz. Postmes, Spears, 
Lee ve Novak, 2005; Reicher ve Sani, 1998) ve veri analizi yöntemlerinde söz konusu farklı yaklaşımları ve yöntemleri bir arada kullanan (örn., tematik analiz için bkz. Fereday ve Muir-Cochrane, 2006) araştırmacılar bulunuyor. Tüm bu çabalara karşın, söz konusu çoklu paradigma ve yöntem anlayışını benimseyen ve bunu toplumsal eşitlik ve özgürleşme gayesiyle hedefleyen ve başaran çok az çalışma bulunuyor.

Bunun dışında, çoklu ve karma araştırma yöntemleri 'kullanılabilir' bir düzleme de çekilebilir. Örneğin, son yıllarda şirketlerin ve vakıfların araştırma fonlarının daha ziyade karma yöntemler içeren araştırmalara ayrıldığı görülüyor (Cosgrove, Wheeler ve Kosterina, 2015). Bu açıdan, özellikle karma yöntemlerin hem (post)pozitivist yaklaŞımların nitel ve nicel yöntemleri birbirine mükemmel şekilde entegre etme dayatmasına karşı hem de mutlak görelilikten kurtulamayan postmodernizmin 1 rkçılık ve ayrımcılık gibi yapısal şiddetleri yok sayma raddesine gelmesine karşı kendini (karşı) konumlandırması öneriliyor (Freshwater ve Fisher, 2015).

\section{TARTIŞMA}

Psikoloji bir bilim dalı olarak kurulduğu günden bu yana hem ontolojik hem de epistemolojik soru(n)larla karşı karşıya: Psikoloji nasıl bir bilim ve amacı ne? Veyahut psikoloji nasıl bilgi üretmeli? Hangi bilgi psikoloji için yeterince bilimseldir? $\mathrm{Bu}$ ve benzeri soruların cevaplarına göre yeni soru(n)lar karşımıza çıkıyor: Başka psikolojiler mümkün mü? Psikoloji bulgularına nasıl erişmeli? Psikoloji hangi yöntemi kullanarak kim(ler) için bilgi üretmeli, bu bilginin niteliği ne olmalı? İnsan davranışlarının evrensel mekanizmalarını ortaya koymayı hedefleyen psikolojinin alt alanları (örneğin sinirbilim araştırmaları) kendisini daha çok doğa bilimleri içinde sınıflandırma çabasındayken, insanların duygu, düşünce ve davranışlarında bağlamın anlamlandırılmasıyla ilgilenen alt alanları kendini daha çok sosyal bilimler içinde görüyor. Yöntem tartışmaları da genellikle bu sınıflandırmadan kaynağını alarak kutuplaşıyor. Öyle ki Wilhelm Wundt, bilincin temel süreçlerine odaklandığı kendi çalışmalarını deneysel ve deneysel-olmayan (kültür psikolojisi; Völkerpsychologie) olarak ikiye ayırmıştı (bkz. Teo, 2001). Bir taraftan sinirbilim araştırmalarını diğer taraftan daha makro olguları (sosyolojik, kültürel ve politik süreçleri) araştıran sosyal psikoloji gibi alt alanlarda ise tartışmanın seyri daha da değişiyor.

Biz bu yazıda, irdelenen olgu kendi bütünlüğü içinde (totalitiät) ele alındığında bütün-tekil ilişkisinin daha tam bir biçimde kavranacağını, böylesi bir yaklaşım sayesinde 
de psikolojinin doğa bilimi mi sosyal bilim mi olduğu şeklindeki sı̆̆ tartışmanın geride bırakılabileceğini vurgulamak istedik. Psikolojinin amacı, belirli bir zaman ve mekandaki koşulları ve bu koşullar içindeki insanın anlamlandırmalarını ve eylemlerini anlamaya katkı sunmak olarak görüldüğünde, bilimsel bilginin belirli sosyotarihsel bağlamlara ve bilim insanlarının değerlerine (benimsedikleri kuramlar gerçeği anlama biçimlerini şekillendirir) içkin olduğu kabul edildiğinde, kuramlar gerçeğin tartışılmasına ve dönüşümüne katk1 sunabilirler (Walsh ve ark., 2014).

Tarihsel olarak bakıldığında, birbiriyle rekabet eden kuramların ve farklı yöntemlerin kullanılmasının bilimin gelişmesini sağladığı görülebilir (Walsh ve ark., 2014). Dolayısıyla, yöntem konusuna eleştirel bir pencereden bakmanın, içinde farklı yöntemlerin ve tekniklerin bulunduğu bir 'alet çantası' metaforuyla yaklaşmanın, psikolojinin yöntembilimsel sorunlarını aşmasında yararlı olabileceğini düşünüyoruz. Teo'nun (2001) belirttiği gibi psikolojinin sofistike yöntemlere ihtiyacı var. Psikolojinin toplumsal sorunların çözümüne katkısı, çoklu ve karma yöntemlerin eleştirel bakış açısıyla alan yazını da dönüştürecek bir amaçla kullanılmasıyla artabilir. Eleştirel bakış açısı için gerekli temel ilkelerle, öznelerarasılık, düşünümsellik ve konumlara/konumlandırmalara yönelik farkındalık ilkeleriyle yola çıktığımızda, bilginin (ve dolayısıyla verinin) türünden (nitel veya nicel) ziyade, bilginin hangi amaçla ve kim için üretildiği daha önemli bir tartışma zemini yaratabilir.

Hakem Değerlendirmesi: Dış bağımsız.

Yazar Katkıları: Çalışma Konsepti/Tasarım- M.G.Y., C.C.; Veri Toplama M.G.Y., C.C.; Veri Analizi/YorumlamaM.G.Y., C.C.; Yazı Taslağı- M.G.Y., C.C.; İçeriğin Eleştirel İncelemesi- M.G.Y., C.C.; Son Onay ve SorumlulukM.G.Y., C.C.

Çıkar Çatışması: Yazarlar çıkar çatışması bildirmemiştir.

Finansal Destek: Yazarlar bu çalışma için finansal destek almadığını beyan etmiştir.

Peer-review: Externally peer-reviewed.

Author Contributions: Conception/Design of Study- M.G.Y., C.C.; Data Acquisition- M.G.Y., C.C.; Data Analysis/ Interpretation- M.G.Y., C.C.; Drafting Manuscript- M.G.Y., C.C.; Critical Revision of Manuscript- M.G.Y., C.C.; Final Approval and Accountability- M.G.Y., C.C.

Conflict of Interest: The authors have no conflict of interest to declare.

Grant Support: The authors declared that this study has received no financial support.

\section{Kaynakça/References}

Acar, G. ve Şahin, D. (1990). Psychology in Turkey. Psychology and Developing Societies, 2, 241-256. https://doi.org/10.1177/097133369000200206

Adams, G. ve Salter, P. H. (2019). They (color) blinded me with science: Counteracting coloniality of knowledge in hegemonic psychology. K.W. Crenshaw, L.C. Harris, D.M. HoSang ve G. Lipsitz 
(ed.), Seeing race again: Countering colorblindness across the disciplines içinde (s. 271-291). Berkeley: University of California Press.

Anguera, M. T., Blanco-Villaseñor, A., Losada, J. L., Sánchez-Algarra, P. ve Onwuegbuzie, A. J. (2018). Revisiting the difference between mixed methods and multimethods: Is it all in the name? Quality \& Quantity, 52(6), 2757-2770. https://doi.org/10.1007/s11135-018-0700-2

Ashworth, P. (2015) (3. bs.). Counceptual foundations of qualitative psychology. J. Smith (Ed.), Qualitative psychology: A practical guide to research methods içinde (s. 4-24). London: Sage.

Astuti, R., Solomon, G. E. A. ve Carey, S. (2004). Constraints on conceptual development: A case study of the acquisition of folkbiological and folksociological knowledge in Madagascar. Monographs of the Society for Research in Child Development, 69(3), 1-161. https://www.jstor.org/stable/3701405

Banister, P., Burman, E., Parker, I., Taylor, M. ve Tindall, C. (1994). Qualitative methods in psychology: A research guide. Buckingham: Open University Press.

Beattie, P., Bettache, K. ve Chong, K. C. Y. (2019). Who is the neoliberal? Exploring the neoliberal beliefs inventory across East and West. Journal of Social Issues, 75(1), 20-48. https://doi. org/10.1111/josi.12309

Bergold, J. B. ve Flick, U. (Ed.). (1987). Ein-Sichten. Zugänge zur Sicht des Subjects mittels qualitativer Forschung. Tübingen: DGVT.

Bettache, K. ve Chiu, C-Y. (2019). The invisible hand is an ideology: Toward a social psychology of neoliberalism. Journal of Social Issues, 75(1), 8-19. https://doi.org/10.1111/josi.12308

Braun, V. ve Clarke, V. (2006). Using thematic analysis in psychology. Qualitative Research in Psychology, 3(2), 77-101. https://doi.org/10.1191/1478088706qp063oa

Braun, V. ve Clarke, V. (2013). Successful qualitative research: A practical guide for beginners. London: Sage.

Bryman, A. (1984). The debate about quantitative and qualitative research: A question of method or epistemology? British Journal of Sociology, 35, 75-92. https://doi.org/10.2307/590553

Burr, V. (1995). An introduction to social constructionism. London: Routledge.

Busch-Jensen, P. ve Schraube, E. (2019). Zooming in zooming out: Analytical strategies of situated generalization in psychological research. C. Højholt ve E. Schraube (Ed.), Subjectivity and knowledge: Generalization in the psychological study of everyday life içinde (s. 221-241). Cham: Springer.

Churchland, P. S. (2019). Nörofelsefe (çev. Ö. Yılmaz). İstanbul: Alfa.

Cipolla, C., Gupta, K., Rubin, D.A. ve Willey, A. (2017). Queer feminist science studies: An introduction. C. Cipolla, K. Gupta, D. A. Rubin ve Willey A. (Ed.), Queer feminist science studies: A reader içinde (s. 3-24). Washington DC: University of Washington Press.

Clarke, V. ve Braun, V. (2019). Feminist qualitative methods and methodologies in psychology: A review and reflection. British Psychological Society, Psychology of Women and Equalities Section Review, 2(1), 13-28.

Cohen, J. (1994). The earth is round ( $<$.05). American Psychologist, 49, 997-1003. https://doi. org/10.1037/0003-066X.49.12.997

Cohen, D. ve Kitayama, S. (2019). Handbook of cultural psychology (2. bs.). New York: Guilford Press. Cosgrove, L., Wheeler, E. E. ve Kosterina, E. (2015). Quantitative methods: Science means and ends. I. Parker (Ed.), Handbook of critical psychology içinde (s. 15-23). New York: Routledge/Taylor \& Francis Group.

Creswell, J. W. (2003). Research design: Qualitative, quantitative, and mixed methods approaches set (2. bs.). Thousand Oaks, CA: Sage. 
Creswell, J. W. ve Plano Clark, V. L. (2007). Designing and conducting mixed methods research. Thousand Oaks, CA: Sage.

Creswell, J. W., Plano Clark, V., Gutmann, M. ve Hanson, W. (2003). Advanced mixed methods research designs. A. Tashakkori ve C. Teddlie (Ed.), Handbook of mixed methods in social and behavioral research içinde (s. 209-240). Thousand Oaks, CA: Sage.

Cushman, P. (1990). Why the self is empty: Toward a historically situated psychology. American Psychologist, 45(5), 599-611. https://doi.org/10.1037/0003-066X.45.5.599

Dege, M. (2019). Rethinking generalization with Kurt Lewin and action research. C. Højholt ve E. Schraube (Ed.), Subjectivity and knowledge: Generalization in the psychological study of everyday life. Theory and history in the human and social sciences içinde (s. 41-60). Cham: Springer.

Denzin, N. K. ve Lincoln, Y. S. (2005). Introduction: The discipline and practice of qualitative research. N. K. Denzin ve Y. S. Lincoln (Ed.), Handbook of qualitative research (3. bs.) içinde (s. 1-32). Thousand Oaks, CA: Sage.

Dilthey, W. (1922/2017). Hermeneutik ve tin bilimleri (Çev. D. Özlem). İstanbul: Notos.

Dutt, A. ve Kohfeldt, D. (2019). Assessing the relationship between neoliberal ideology and reactions to Central American asylum seekers in the United States. Journal of Social Issues, 75(1), 134-152. https://doi.org/10.1111/josi.12312

Ebbesen, C. L. (2020, June 17). Flawed estimates of cognitive ability in Clark et al. Psychological Science, 2020. https://doi.org/10.31234/osf.io/tzr8c

Engels, F. (1876-78/1977). Anti-Dühring (Çev. K. Somer). Ankara: Sol.

Farr, R. (1987). Social representations: A French tradition of research. Journal of the Theory of Social Behaviour, 17(4), 343-69.

Fereday, J. ve Muir-Cochrane, E. (2006). Demonstrating rigor using thematic analysis: A hybrid approach of inductive and deductive coding and theme development. International Journal of Qualitative Methods, 5, 80-92. https://doi.org/10.1063/1.2011295

Ferguson, C. J. ve Brannick, M. T. (2012). Publication bias in psychological science: Prevalence, methods for identifying and controlling, and implications for the use of meta-analyses. Psychological Methods, 17(1), 120-128. https://doi.org/10.1037/a0024445

Fisher, R. A. (1925). Statistical methods for research workers. London: Oliver \& Boyd.

Francis, G. (2012a). The psychology of replication and replication in psychology. Perspectives on Psychological Science, 7(6) 585-594. https://doi.org/10.1177/1745691612459520

Francis, G. (2012b). Too good to be true: Publication bias in two prominent studies from experimental psychology. Psychonomic Bulletin and Review, 19, 151-156. https://doi.org/10.3758/s13423-0120227-9

Freshwater, D. ve Fisher, P. (2015). Mixed methods dissonance and values in research with marginalized groups. S. Hesse-Biber ve R. Burke Johnson (Ed.), The Oxford handbook of multimethod and mixed methods research inquiry içinde (s. 665-676). New York, NY: Oxford University Press.

Gannon, L., Luchetta, T., Rhodes, K., Pardie, L. ve Segrist, D. (1992). Sex bias in psychological research: Progress or complacency?. American Psychologist, 47(3), 389. https://doi.org/10.1037/0003066X.47.3.389

Gergen, K. J. (1973). Social psychology as history. Journal of Personality and Social Psychology, 26(2), 309-320. https://doi.org/10.1037/h0034436

Gergen, K. J. (1985). The social constructionist movement in modern psychology. American Psychologist, 40(3), 266-275. https://doi.org/10.1037/0003-066X.40.3.266

Gergen, K. J. (1999). An invitation to social construction. London: Sage. 
Gjorgjioska, M. A. ve Tomicic, A. (2019). The crisis in social psychology under neoliberalism: Reflections from Social Representations Theory. Journal of Social Issues, 75(1), 169-188. https:// doi. org/10.1111/josi.12315

Greene, J. C. ve Caracelli, V. J. (Ed.). (1997a). Advances in mixed-method evaluation: The challenges and benefits of integrating diverse paradigms, No. 74. San Francisco: Jossey-Bass.

Greene, J. C. ve Caracelli, V. J. (1997b). Defining and describing the paradigm issue in mixed-method evaluation. J. C. Greene ve V. J. Caracelli (Ed.), Advances in mixed-method evaluation: The challenges and benefits of integrating diverse paradigms, No. 74 içinde (s. 5-17). San Francisco: Jossey-Bass.

Greene, J. C. ve Caracelli, V. J. (2003). Making paradigmatic sense of mixed-method practice. A. Tashakkori ve C. Teddlie (Ed.), Handbook of mixed methods in social and behavioral research içinde (s. 91-110). Thousand Oaks, CA: Sage.

Guba, E. G. (1987). What have we learned about naturalistic evaluation? Evaluation Practice, 8, 23-43. https://doi.org/10.1016/S0886-1633(87)80037-5

Guba, E. G. ve Lincoln, Y. S. (1994). Competing paradigms in qualitative research. N. K. Denzin ve Y. S. Lincoln (Ed.), Handbook of qualitative research içinde (s. 105-117). Thousand Oaks, CA: Sage.

Guba, E. G. ve Lincoln, Y. S. (2005). Paradigmatic controversies, contradictions, and emerging confluences. N. K. Denzin ve Y. S. Lincoln (Ed.), Handbook of qualitative research (3. bs.) içinde (s. 191-215). Thousand Oaks, CA: Sage.

Hartwich, L. ve Becker, J. C. (2019). Exposure to neoliberalism increases resentment of the elite via feelings of anomie and negative psychological reactions. Journal of Social Issues, 75(1), 113-133. https://doi.org/10.1111/josi.12311

Head, M. L., Holman, L., Lanfear, R., Kahn, A. T. ve Jennions, M. D. (2015). The extent and consequences of p-hacking in science, Plos Biology, 13(3), e1002106. https://doi.org/10.1371/ journal.pbio. 1002106

Henningsen, P. ve Kirmayer, L. J. (2000). Mind beyond the net: Implications of cognitive neuroscience for cultural psychiatry. Transcultural Psychiatry, 37(4), 467-494. https://doi. org/10.1177/136346150003700401

Henrich, J., Heine, S. J. ve Norenzayan, A. (2010). The weirdest people in the world? Behavioral and Brain Sciences, 33, 61-83. https://doi.org/10.1017/S0140525X0999152X

Herek, G. M., Kimmel, D. C., Amaro, H. ve Melton, G. B. (1991). Avoiding heterosexist bias in psychological research. American Psychologist, 46(9), 957-963. https://doi.org/10.1037/0003066X.46.9.957

Hesse-Biber, S. (2015). Introduction: Navigating a turbulent research landscape. Working the boundaries, tensions, diversity, and contradictions of multimethod and mixed methods inquiry. S. Hesse-Biber ve B. Johnson (Ed.), Oxford handbook of multimethod and mixed methods research inquiry içinde (s. xxxiii-iiii). Oxford, UK: Oxford University Press.

Holtz, P. ve Monnerjahn, P. (2017). Falsificationism is not just 'potential' falsifiability, but requires 'actual' falsification: Social psychology, critical rationalism, and progress in science. Journal for the Theory of Social Behaviour, 47(3), 348-362. https://doi.org/10.1111/jtsb.12134

Holzkamp, K. (1973). Sinnliche Erkenntnis: Historischer Urspung und geselschaftliche Funktion der Wahrnehmung. Frankfurt am Main, Germany: Athenaum.

Hope, E. C., Brugh, C. S. ve Nance, A. (2019). In search of a critical stance: Applying qualitative research practices for critical quantitative research in psychology. Community Psychology in Global Perspective, 5(2), 63-69. https://doi.org/10.1285/i24212113v5i2p63 
Howarth, C. (2006). How social representations of attitudes have informed attitude theories: The consensual and the reified. Theory \& Psychology, 16(5), $691714 . \quad$ https://doi. org/10.1177/0959354306067443

Howitt, D. (2010). Introduction to qualitative methods in psychology. Harlow: Pearson Education Ltd. Højholt, C. ve Schraube, E. (2019) (Ed.). Subjectivity and knowledge: Generalization in the psychological study of everyday life. Cham: Springer.

Ioannidis, J. P. A. (2005). Why most published research findings are false. PLoS Medicine, 2(8), e124. https://doi.org/10.1371/journal.pmed.0020124

Kağıtçıbaş1, C. (1994). Psychology in Turkey. International Journal of Psychology, 29, 729-738. https://doi.org/10.1080/00207599408246562

Kitayama, S., Varnum, M. E. W. ve Salvador, C. M. (2019). Cultural neuroscience. D. Cohen ve S. Kitayama (Ed.), Handbook of cultural psychology (2. bs.) içinde (s. 79-118). New York: Guilford Press.

Lefebvre, H. (1981/2010). Gündelik hayatın eleştirisi III: Moderniteden modernizme (gündelik hayatın meta-felsefesi) (2. bs.). İstanbul: Sel.

Lewin, K. (1931). The conflict between Aristotelian and Galileian modes of thought in contemporary psychology. Journal of General Psychology, 5, 141-177. https://doi.org/10.1080/00221309.1931. 9918387

Lewin, K. (1939). Field theory and experiment in social psychology. American Journal of Sociology, 44(6), 868-896. https://doi.org/10.1086/218177

Lincoln, Y. S. ve Guba, E. G. (1985). Naturalistic inquiry. Thousand Oaks, CA: Sage.

Markus, H. R. ve Hamedani, M. G. (2019). People are culturally shaped shapers: The psychological science of culture and culture change. D. Cohen ve S. Kitayama (Ed.), Handbook of cultural psychology (2. bs.) içinde (s. 11-52). New York: Guilford Press.

Maxwell, J. ve Loomis, D. (2003). Mixed methods design: An alternative approach. A. Tashakkori ve C. Teddlie (Ed.), Handbook of mixed methods in social and behavioral research içinde (s. 241272). Thousand Oaks, CA: Sage.

Mayring, P. (2002). Einführung in die qualitative Sozialforschung (5. bs.). Weinheim: Beltz Verlag.

Mayring, P. (1989). Die qualitative Wende: Grundlagen, Techniken und Integrationsmöglichkeiten qualitativer Forschung in der Psychologie. W. Schönpflug (Ed.), Bericht über den 36. Kongress der Deutschen Gesellschaft für Psychologie in Berlin 1988. Band 2 içinde (s. 306-313). Göttingen: Hogrefe.

Meehl, P. E. (1997). The problem is epistemology, not statistics: Replace significance tests by confidence intervals and quantify accuracy of risky numerical predictions. L. L. Harlow, S. A. Mulaik ve J. H. Steiger (Ed.), What if there were no significance tests? içinde (s. 393-425). London: Routledge.

Metraux, A. (1985). Der Methodenstreit und die Amerikanisierung der Psychologie in der Bundesrepublik 1950-1970. M. G. Ash ve U. Geuter (Ed.), Geschichte der deutschen Psychologie im 20. Jahrhundert içinde (s. 225-251). Opladen: Westdeutscher Verlag.

Moscovici, S. (1981). On social representations. J. Forgas (Ed.), Social cognition içinde (s. 181-209). London: Academic Press.

Nosek, B. A., Alter, G., Banks, G. C., Borsboom, D., Bowman, S. D., Breckler, S. J., ... ve Contestabile, M. (2015). Promoting an open research culture. Science, 348(6242), 1422-1425. https://doi. org/10.1126/science.aab2374

Panno, A., Leone, L. ve Carrus, G. (2019). Attitude towards Trump policies and climate change: The key roles of aversion to wealth redistribution and political interest. Journal of Social Issues, 75(1), 
153-168. https://doi.org/10.1111/josi.12318

Parker, I. (1990). Discourse: Definitions and contradictions. Philosophical Psychology. 3, 189-204. https://doi.org/10.1080/09515089008572998

Parker, I. (1999). Critical psychology: Critical links. Annual Review of Critical Psychology, 1, 3-18.

Parker, I. (2015). Handbook of critical psychology. London: Routledge.

Pashler, H. ve Wagenmakers, E. J. (2012). Editors' introduction to the special section on replicability in psychological science a crisis of confidence?. Perspectives on Psychological Science, 7(6), 528 530. https://doi.org/10.1177/1745691612465253

Patton, M. Q. (2002). Qualitative research and evaluation methods (3. bs.). Thousand Oaks, CA: Sage.

Pettigrew, T. F. (2018). The emergence of contextual social psychology. Personality and Social Psychology Bulletin, 44(7), 963-971. https://doi.org/10.1177/0146167218756033

Popper, K. (1959). The logic of scientific discovery. Oxford: Basic Books.

Postmes, T., Spears, R., Lee, A. T. ve Novak, R. J. (2005). Individuality and social influence in groups: Inductive and deductive routes to group identity. Journal of Personality and Social Psychology, 89(5), 747-763. http://dx.doi.org/10.1037/0022-3514.89.5.747

Reicher, S. (1997). Laying the ground for a common critical psychology. T. Ibáñez ve L. Íñiguez (Ed.), Critical social psychology içinde (s. 83-94). London: Sage.

Reicher, S. ve Sani, F. (1998). Introducing SAGA: Structural analysis of group arguments. Group Dynamics: Theory, Research, and Practice, 2(4), 267-284. https://doi.org/10.1037/10892699.2.4.267

Reicher, S. D., Spears, R. ve Haslam, S. A. (2010). The social identity approach in social psychology. M. Wetherell ve C. T. Mohanty, (Ed.), The Sage handbook of identities içinde (s. 45-62). London: Sage.

Reichertz, J. (2010). Abduction: The logic of discovery of grounded theory. Forum: Qualitative Social Research, 11(1). http://www.qualitative-research.net/index.php/fqs/article/view/1412/2902

Richards, G. (2012). 'Race', racism and psychology: Towards a reflexive history. London: Rouledge.

Rosenthal, R. (1979). The file drawer problem and tolerance for null results. Psychological Bulletin, 86, 638-641. https://doi.org/10.1037/0033-2909.86.3.638

Roy, D. ve Subramaniam, B. (2016). Matter in the shadows: Feminist new materialism and the practices of colonialism. V. Pitts-Taylor (Ed.), Mattering: Feminism, science and materialism içinde (s. 2342). New York: NYU Press.

Said, E. (1978). Orientalism. U.S.: Pantheon Books.

Sale, J., Lohfeld, L. ve Brazil, K. (2002). Revisiting the qualitative-quantitative debate: Implications for mixed-methods research. Quality and Quantity, 36, 43-53. https://doi. org/10.1023/A:1014301607592

Shadish, W. R. (1995). Philosophy of science and the quantitative-qualitative debates: Thirteen common errors. Evaluation and Program Planning, 18, 63-75. https://doi:10.1016/0149-7189(94)00050-8

Simmons, J. P., Nelson, L. D. ve Simonsohn, U. (2011). False-positive psychology: Undisclosed flexibility in data collection and analysis allows presenting anything as significant. Psychological Science, 22(11), 1359-1366. https://doi.org/10.1177/0956797611417632

Smith, J. K. (1983). Quantitative versus qualitative research: An attempt to clarify the issue. Educational Researcher, 12, 6-13. https://doi.org/10.3102/0013189X012003006

Subasic, E., Hardacre, S. L. Elton, B., Branscombe, N. R., Ryan, M. K. ve Reynolds, K. J. (2018). "We for she": Mobilising men and women to act in solidarity for gender equality. Group Processes \& Intergroup Relations, 21(5), 707-724. https://doi.org/10.1177/1368430218763272 
Tajfel, H. ve Turner, J. C. (1979). An integrative theory of inter-group conflict. W. G. Austin ve S. Worchel (Ed.), The social psychology of inter-group relations içinde (s. 33-47). Monterey, CA: Brooks/Cole.

Tebes, J. K. (2005). Community science, philosophy of science, and the practice of research. American Journal of Community Psychology, 35(3-4), 213-230. https://doi.org/10.1007/s10464-005-3399-x

Teddlie, C. ve Tashakkori, A. (2009). Foundations of mixed methods research: Integrating quantitative and qualitative approaches in the social and behavioral sciences. London: Sage.

Teo, T. (1999). Methodologies of critical psychology: Illustrations from the field of racism. Annual Review of Critical Psychology, 1, 119-134.

Teo, T. (2001). Karl Marx and Wilhelm Dilthey on the socio-historical conceptualization of the mind. C. D. Green, M. Shore ve T. Teo (Ed.), The transformation of psychology: Influences of 19thcentury philosophy, technology, and natural science içinde (s. 195-218). American Psychological Association. https://doi.org/10.1037/10416-010

Teo, T. (2008). From speculation to epistemological violence in psychology: A critical-hermeneutic reconstruction. Theory and Psychology, 18(1), 47-67.

Teo, T. (2010). What is epistemological violence in the empirical social sciences? Social and Personality Psychology Compass, 4(5), 295-303.

Teo, T. (2011). Empirical race psychology and the hermeneutics of epistemological violence. Human Studies, 34(3), 237-255.

Triandis, H. C., \& Brislin, R. W. (1984). Cross-cultural psychology. American Psychologist, 39(9), $1006-1016$.

Verfaellie, M. ve McGwin, J. (2011). The case of Diederik Stapel. American Psychological Assosication. https://www.apa.org/science/about/psa/2011/12/diederik-stapel. Erişim tarihi: 20 Ocak 2021.

Walsh, R., Teo, T. ve Baydala, A. (2014). A critical history and philosophy of psychology: Diversity of context, thought, and practice. Cambridge: Cambridge University Press.

Willey, A. (2016). Biopossibility: A queer feminist materialist science studies manifesto, with special reference to the question of monogamous behavior. Signs: Journal of Women in Culture and Society, 41(3), 553-577.

Willig, C. (2012). Perspectives on the epistemological bases for qualitative research. H. Cooper, P. M. Camic, D. L. Long, A. T. Panter, D. Rindskopf ve K. J. Sher (Ed.), APA handbooks in psychology ${ }^{\circledR}$. APA handbook of research methods in psychology, Vol. 1. Foundations, planning, measures, and psychometrics içinde (s. 5-21). American Psychological Association. https://doi. org/10.1037/13619-002

Witzel, A. (1982). Verfahren der qualitativen Sozialforschung. Überblick und Alternativen. Frankfurt: Campus.

Zelazo, P. D. ve Paus, T. (2010). Developmental social neuroscience: An introduction. Social Neuroscience, 5(5-6), 417-421. https://doi.org/10.1080/17470919.2010.510002 
